\title{
Synthesis of Functionalized Cyclopropanes by MIRC Reactions of Aziridinyl-methylenemalonates.
}

\author{
Ikuo Funaki, Roel P.L. Bell, Lambertus Thijs and Binne Zwanenburg* \\ Department of Organic Chemistry, NSR Center for Molecular Structure, Design and Synthesis, University of \\ Nijmegen, Toernooiveld, 6525 ED Nijmegen, The Netherlands
}

\begin{abstract}
The synthesis of cyclopropane derivatives via a MIRC reaction of azidirinyl-methylenemalonates is described. In this way it is possible to introduce a hydrogen, a phenylthio, a tributylstannyl and an olefinic function at the cyclopropane ring, that further contains an alkylamino substituent. Addition of $\mathrm{CuCN}$ catalyzed Grignard reagents gave the most promising results. The diastereoselectivity was dependent on the aziridine nitrogen substituent and the bulkiness of the reagent.

Copyright (C) 1996 Elsevier Science Ltd
\end{abstract}

\section{INTRODUCTION}

The intramolecular ring opening of aziridinecarboxamides by a nucleophilic center at the $y$-atom in the carboxamide part was the subject of a previous paper from our laboratories." The required nucleophilic site was generated by removal of a suitable acidic proton leading in general to a highly substituted lactam. To further explore intramolecular ring-opening reactions of functionalized aziridines, the inducing nucleophilic site was positioned at the $\beta$-atom relative to the aziridine-ring. In principle, such a nucleophile can be obtained by a deprotonation process. However, an alternative method was chosen, which was inspired by the work of Kasatkin et al. 'These authors reported recently the synthesis of cyclopropane dicarboxylates using Michaelreaction Initiated Ring Closure (MIRC) reactions ${ }^{2,3}$ of diethyl (2, 3-epoxybutylidene)malonate (Scheme 1).

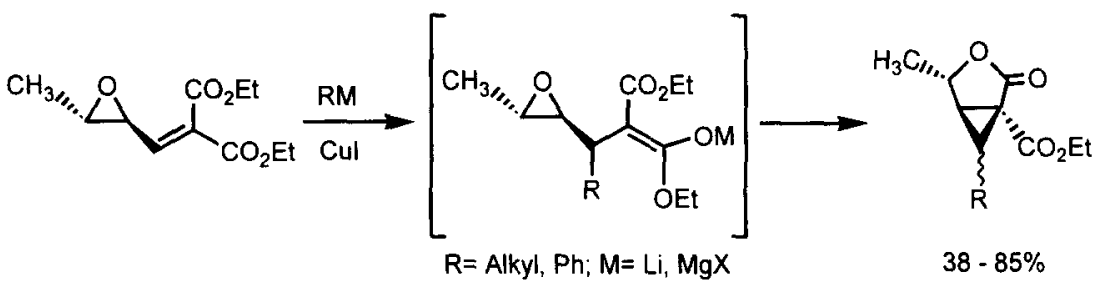

Scheme 1

Application of the MIRC reaction in an analogous manner to activated aziridines could be of interest and could illustrate the potential of aziridinyl-methylenemalonates for the synthesis of functionalized cyclopropanes. ${ }^{4}$ However, aziridinyl-methylenemalonates can react with a nucleophile by two distinctly different pathways, as is shown in scheme 2 . The desired pathway $a$ involves conjugate addition of the nucleophile followed by opening of the aziridine ring. The alternative pathway $b$ is a direct nucleophilic opening of the three-membered ring. In the proposed scheme 2, the choice of the $\mathrm{N}$-activating group may be of great importance for the success of the reaction. Reactions of $\beta$-aziridinyl- $\alpha, \beta$-enoates with organo-copper reagents have been investigated whereby predominantly anti $-\mathrm{S}_{\mathrm{N}} 2^{1}$ products are produced. ${ }^{5}$ In the system which 
is proposed for the present investigations, such an $\mathrm{S}_{\mathrm{N}} 2^{1}$ reaction seems highly improbable because of the strongly activated methylenemalonates and is therefore not further taken into account. ${ }^{2 b}$ The formation of fourmembered ring systems instead of three-membered was not observed.

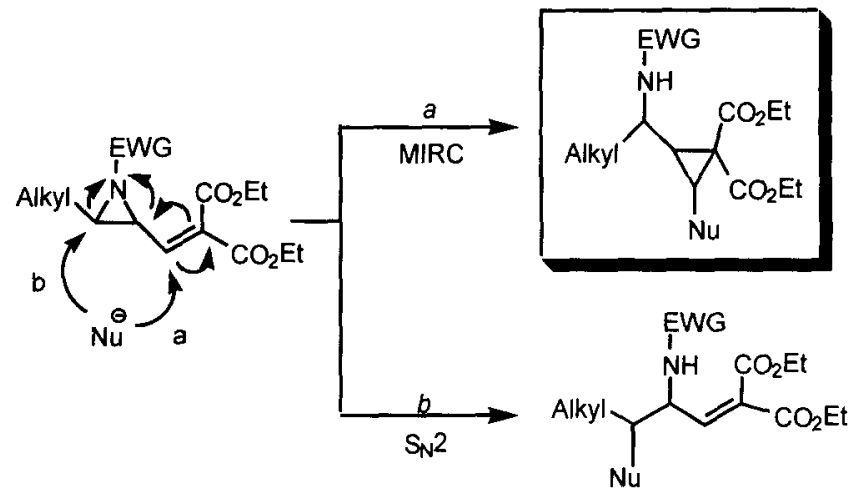

(Nucleophilic attack at the C-2 aziridine carbon is omitted in this scheme.)

Scheme 2

\section{RESULTS AND DISCUSSION}

Preparation of diethyl aziridinyl-methylenemalonate derivatives. The required aziridines 3 were prepared as shown in Scheme 3. For this study racemic aziridines ${ }^{6}$ were used because the prime interest was the diastereoselectivity during the Michael additions. Direct reduction of 1-tosyl-3-hexyl-aziridine-2-carboxylic acid ethyl ester $1 \mathrm{a}$ to the aldehyde $2 \mathbf{a}^{7}$ followed by condensation with diethyl malonate afforded diethyl aziridinyl-methylenemalonate 3a. ${ }^{8}$ 1-Mesyl-3-hexyl-aziridine derivative 3b, 1-tosyl-3-methyl-aziridine 3c, 1-(2mesityl-sulfonyl)-3-methyl-aziridine 3d and 1-(2-mesitylsulfonyl)-3-hexyl-aziridine 3e were prepared similarly. In the condensation using $\mathrm{TiCl}_{4}$-pyridine, chlorinated side-products were observed as a result of aziridine ringopening reactions. The degree of chlorination differed among substrates 3, and depended on the 2-substituents and sulfonyl groups (from $0 \%$ for $\mathbf{3 e}$ to $41 \%$ for $\mathbf{3 a}$ ).

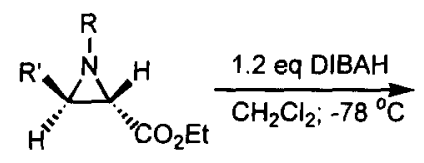

1a; $\mathrm{R}=-\mathrm{SO}_{2}$-Tol $(\mathrm{Ts}), \mathrm{R}^{\prime}=\mathrm{Hex}$ 1b; $\mathrm{R}=-\mathrm{SO}_{2}-\mathrm{CH}_{3}(\mathrm{Ms}), \mathrm{R}^{\prime}=\mathrm{Hex}$

1c; $R=T s, R^{\prime}=M e$

1d; $\mathrm{R}=-\mathrm{SO}_{2}-2,4,6-\left(\mathrm{CH}_{3}\right)_{3} \mathrm{C}_{6} \mathrm{H}_{2}, \mathrm{R}^{\prime}=\mathrm{Me}$

1e; $\mathrm{R}=-\mathrm{SO}_{2}-2,4,6-\left(\mathrm{CH}_{3}\right)_{3} \mathrm{C}_{6} \mathrm{H}_{2}, \mathrm{R}^{\prime}=\mathrm{Hex}$

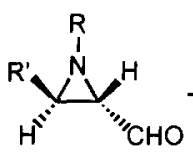

$2 \mathrm{a}(84 \%)$

$2 b(86 \%)$

2c $(41 \%)$

2d $(91 \%)$

2e $(59 \%)$

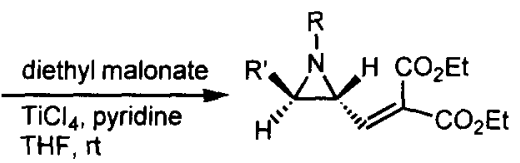

$3 a(52 \%)$

$3 \mathrm{~b}(62 \%)$

3c $(65 \%)$

$3 d(95 \%)$

3 e $(97 \%)$

Scheme 3

Reactions of 1-tosyl-aziridine derivative 3a. Several products can result from these reactions of 3 (vide supra). Compounds 4 and 7 (Scheme 4) are the result of a conjugate reaction. Subsequent cyclization of the initial products 4 and 7 leads to cyclopropanes 5 and 8 , respectively. The compounds 6 and 9 are the result of a direct $\mathrm{S}_{\mathrm{N}}$ 2-type opening of the aziridine ring (see pathway $b$ in Scheme 2). The diastereomer ratio's of the cyclopropanes 5 and 8 were determined by $400 \mathrm{MHz}{ }^{1} \mathrm{H}$ NMR spectroscopy. 


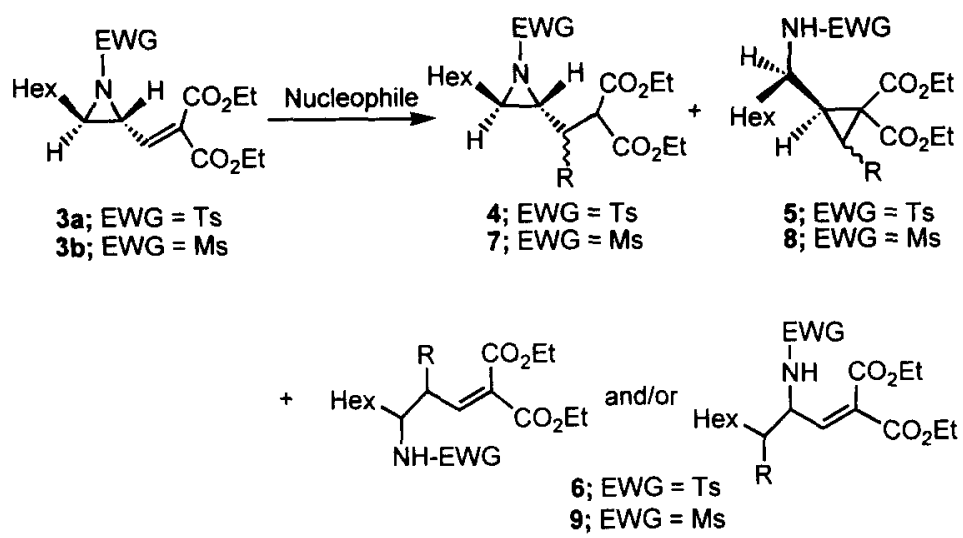

Scheme 4

It was felt that organocuprate reagents should be suitable for selective MIRC reactions because of their high conjugate addition potential ${ }^{9}$. When higher order organocuprates were used (Table 1), dimethyl

Table 1. Reactions of aziridinyl-methylenemalonate 3a with various nucleophilic reagents

\begin{tabular}{|c|c|c|c|c|}
\hline \multirow[t]{2}{*}{ Entry } & \multirow[t]{2}{*}{ Reaction Conditions } & \multirow[t]{2}{*}{$\mathrm{R}$} & \multicolumn{2}{|c|}{ Product (yield in \%) } \\
\hline & & & 4 & 5 \\
\hline 1 & $\mathrm{Me}_{2} \mathrm{Cu}(\mathrm{CN}) \mathrm{Li}_{2}, \mathrm{Et}_{2} \mathrm{O},-30^{\circ} \mathrm{C}, 3 \mathrm{~h}$ & $\mathrm{Me}$ & $4 a(0)$ & $5 a(59)^{a}$ \\
\hline 2 & $\mathrm{Bu}_{2} \mathrm{Cu}(\mathrm{CN}) \mathrm{Li}_{2}, \mathrm{Et}_{2} \mathrm{O},-30^{\circ} \mathrm{C}, 3 \mathrm{~h}$ & $\mathrm{Bu}$ & $4 b(24)$ & $5 b$ (trace) \\
\hline 3 & $\mathrm{Bu}_{2} \mathrm{Cu}(\mathrm{CN}) \mathrm{Li}_{2} \mathrm{BF}_{3}, \mathrm{El}_{2} \mathrm{O},-30^{\circ} \mathrm{C}, 3 \mathrm{~h}$ & $\mathrm{Bu}$ & $4 b(54)$ & $5 \mathbf{b} / 6 \mathbf{b}(27)^{\mathrm{b}}$ \\
\hline 4 & $\mathrm{BuCu}(\mathrm{CN}) \mathrm{MgBr} \mathrm{BF}_{3}, \mathrm{Et}_{2} \mathrm{O},-30^{\circ} \mathrm{C}, 3 \mathrm{~h}$ & $\mathrm{Bu}$ & $4 b(29)$ & $5 \mathbf{b}(53)^{c}$ \\
\hline 5 & $\mathrm{BuCu}(\mathrm{CN}) \mathrm{MgBr} \mathrm{BF}_{3}, \mathrm{THF},-30^{\circ} \mathrm{C}, 3 \mathrm{~h}$ & $\mathrm{Bu}$ & $4 b(65)$ & $5 \mathbf{b}$ (trace) \\
\hline 6 & $\begin{array}{l}\text { BuMgBr, } 10 \mathrm{~mol} \% \mathrm{CuCN}, \mathrm{Et}_{2} \mathrm{O} \text {, } \\
-78^{\circ} \mathrm{C}-\mathrm{rt}, 2 \mathrm{~h}\end{array}$ & $\mathrm{Bu}$ & $4 b(0)$ & $5 b(91)^{d}$ \\
\hline 7 & $\begin{array}{l}\left(\text { Vinyl) } \mathrm{MgBr}, 10 \mathrm{~mol} \% \mathrm{CuCN}, \mathrm{Et}_{2} \mathrm{O}\right. \\
-78^{\circ} \mathrm{C}-\mathrm{rt}, 4 \mathrm{~h}\end{array}$ & Vinyl & $4 c(31)^{e}$ & $5 c(44)^{f}$ \\
\hline 8 & $\begin{array}{l}\mathrm{Bu}_{2} \mathrm{C}=\mathrm{CH}-\mathrm{CuMgBr} \mathrm{SMe}_{2} \\
\mathrm{Et}_{2} \mathrm{O},-30-0^{\circ} \mathrm{C}, 4 \mathrm{~h}\end{array}$ & $\mathrm{Bu}_{2} \mathrm{C}=\mathrm{CH}-$ & $4 d(0)$ & 5d $(51)^{f}$ \\
\hline 9 & $\left(\mathrm{Bu}_{3} \mathrm{Sn}\right) \mathrm{BuCu}(\mathrm{CN}) \mathrm{Li}_{2}, \mathrm{Et}_{2} \mathrm{O},-30^{\circ} \mathrm{C}, 3 \mathrm{~h}$ & $\mathrm{Bu}_{3} \mathrm{Sn}$ & $4 e(16)$ & $5 e(30)^{g}$ \\
\hline 10 & $\mathrm{PhSNa}, \mathrm{THF},-50^{\circ} \mathrm{C}, 3 \mathrm{~h}$ & Phs & $4 f(64)$ & $5 f(0)$ \\
\hline 11 & K-Selectride, THF, $0^{\circ} \mathrm{C}, 1 \mathrm{~h}$ & $H$ & $\mathbf{4 g}(0)$ & $\mathbf{s g}(79)$ \\
\hline
\end{tabular}

a $1: 1$ Mixture of cis/trans diastereomers. ${ }^{b}$ Total yield of the mixture is shown. $5 \mathbf{b}: 6 \mathbf{b}$ $=45: 55$. Cisitrans ratio of $5 \mathrm{~b}, \mathrm{ca} .65: 35$. "The minor diastereomer could not be detected by ${ }^{1} \mathrm{H}$ NMR spectroscopy. ${ }^{d}$ Cis/trans ratio $85: 15$. ${ }^{e}$ Cis/trans ratio not determined. ${ }^{\dagger}$ Cis/trans ratio 90:10. ${ }^{9}$ Cis/trans ratio 75:25.

cyanocuprate gave cyclopropane 5 a (entry 1 ), but, the dibutyl derivative gave a very poor result (entry 2 ). Three equivalents of reagent were used in these reactions to obtain acceptable yields (entries 1-5). Boron trifluoride etherate has been reported as an effective co-additive for organocuprates, ${ }^{10}$ and $\mathrm{Bu}_{2} \mathrm{Cu}(\mathrm{CN}) \mathrm{Li}_{2} \mathrm{BF}_{3}$ did indeed 
improve the conjugate addition (entry 3). As an alternative butyl-donor, $\mathrm{BuCu}(\mathrm{CN}) \mathrm{MgBr} \cdot \mathrm{BF}_{3} \cdot \mathrm{OEt}_{2}$ was used and it showed high reactivity and isomeric selectivity (entry 4 ). The cyclopropane derivative $\mathbf{5 b}$ was obtained uncontaminated with the $S_{N} 2$ reaction products $6 \mathbf{b}$. It is of interest that when tetrahydrofuran was used as solvent, only the conjugate addition product $\mathbf{4 b}$ was obtained containing only traces of cyclization product $\mathbf{5 b}$ (entry 5).

It was found necessary to carry out the reaction at higher temperatures in order to improve the chemical yield further. But, use of excess of reagents ( 3 equiv; entries 1-5) does not permit higher reaction temperatures since organocuprate reagents are known to open the aziridine ring at a temperature higher than $-20{ }^{\circ} \mathrm{C} .11$ Therefore a stoichiometric amount of Grignard reagent was added in the $\mathrm{CuCN}$ catalyzed reaction (entry 6). This resulted in an excellent yield with high degree of stereoselectivity (85:15). Although the vinyl group could also be introduced, a considerable amount of uncyclized product $4 \mathbf{c}$ was observed even after a prolonged reaction time (4h) at room temperature (entry 7). Whilst the stereoselectivity of $5 \mathrm{c}$ was surprisingly high (90:10) for this small nucleophile, the diastereomer ratio of $\mathbf{4 c}$ could not be determined (it was likely to be low, considering the low diastereoselectivity observed during the methyl introduction in entry 1). It was assumed that a high stereoselectivity for the introduction of an unsaturated function might be achieved with a more sterically hindered group. For this purpose, alkenylcoppermagnesium dibromide ${ }^{12}$ was prepared in situ and submitted to the MIRC reaction (entry 8). Although the chemical yield was moderate, a high stereoselectivity was observed (90:10).

Lipshutz et al. reported the direct formation of trialkyltin cuprates from tin hydrides. ${ }^{13}$ The alkylstannyl function is of value because of its potential for lithium-transmetalation with stereo-retention. ${ }^{14}$ Tributyltin cuprate transferred the tributyltin group in moderate yield (entry 9) with a disappointing stereoselectivity $(75: 25)$.

Sodium thiophenoxide, another nucleophilic reagent, gave conjugate addition product $\mathbf{4 f}$ only (entry 10), and K-selectride transferred hydride to ultimately give cyclopropane derivative $\mathbf{5 g}$ in good yield (entry 11$){ }^{15}$

Reactions of 1 -mesyl-aziridine derivative $3 \mathbf{b}$. The reactions of the aziridine derivative $3 \mathbf{b}$, which carries the methylsulfonyl (mesyl) group as the aziridine-activating group were examined briefly (Table 2).

Table 2. Reactions of aziridinyl-methylenemalonate $\mathbf{3 b}$ with various nucleophilic reagents

\begin{tabular}{clccc}
\hline Entry & Reaction Conditions ${ }^{\mathrm{a}}$ & $\mathrm{R}$ & \multicolumn{2}{c}{ Product (yield in \%) } \\
& & & 7 & $\mathbf{8}$ \\
\hline 1 & $\mathrm{Me}_{2} \mathrm{Cu}(\mathrm{CN}) \mathrm{Li}_{2}, \mathrm{Et}_{2} \mathrm{O}$ & $\mathrm{Me}$ & $\mathbf{7 a}(42)$ & $\mathbf{8 a} / 9 \mathbf{a}(38)^{\mathrm{b}}$ \\
2 & $\mathrm{Bu}_{2} \mathrm{Cu}(\mathrm{CN}) \mathrm{Li}_{2}, \mathrm{Et}_{2} \mathrm{O}$ & $\mathrm{Bu}$ & $\mathbf{7 b}(40)$ & $\mathbf{8 b}(16)^{\mathrm{c}}$ \\
3 & $\mathrm{Bu}_{2} \mathrm{Cu}(\mathrm{CN}) \mathrm{Li}_{2} \cdot \mathrm{BF}_{3}, \mathrm{Et}_{2} \mathrm{O}$ & $\mathrm{Bu}$ & $\mathbf{7 b}(23)$ & $\mathbf{8 b}(23)^{\mathrm{c}}$ \\
4 & $\mathrm{Bu}_{2} \mathrm{Cu}(\mathrm{CN}) \mathrm{Li}_{2}, \mathrm{THF}$ & $\mathrm{Bu}$ & $\mathbf{7 b}(43)$ & $\mathbf{8 b}($ trace $)$ \\
\hline
\end{tabular}

a $-30^{\circ} \mathrm{C}, 3 \mathrm{~h} . \quad{ }^{\mathrm{b}} \mathrm{R}=\mathrm{H}$ in $9 \mathrm{a}$, Cistrans ratio of $8 \mathrm{a}$ ca. 55:45. Total yield of the mixture is

shown. 8a/9a $=83: 17$. ${ }^{\mathrm{C}}$ The minor diastereomer was not detected by ${ }^{1} \mathrm{H}$ NMR spectroscopy.

The reaction trend of $\mathbf{3 b}$ was almost the same as that of $\mathbf{3 a} . \mathrm{Me}_{2} \mathrm{Cu}(\mathrm{CN}) \mathrm{Li}_{2}$ showed approximately the same degree of stereoselectivity with $\mathbf{3 b}$ (ca. 55:45 ratio; Table 2, entry 1). Surprisingly, a considerable amount of uncyclized product 7a was observed. ${ }^{16}$ The cyclopropane $8 \mathbf{a}$ was obtained as an inseparable mixture with $9 \mathrm{a}$ $(\mathrm{R}=\mathrm{H}) .{ }^{11 \mathrm{a}, 17} \mathrm{Bu}_{2} \mathrm{Cu}(\mathrm{CN}) \mathrm{Li}_{2}$ reacted with an almost exclusive stereoselectivity in contrast to the reaction of $3 \mathbf{a}$ 
(Table 1, entry 3, and Table 2, entry 2), and the cyclopropane $8 \mathbf{b}$ could be isolated. In contrast to the accelerative effect of $\mathrm{BF}_{3}$ on $\mathbf{3 a}$, the organocuprate boron trifluoride complex did not dramatically change the outcome of the reaction of $\mathbf{3 b}$ (entry 3). Although the exclusive formation of one diastereomer $\mathbf{8 b}$ was impressive, the stereoselectivity during the reactions of $\mathbf{3 b}$ with the butylorganocuprate reagents is in the same range as that observed for $\mathbf{3 a}$. The high diastereopurity of $\mathbf{5 b}$ was also observed (Table 1, entry 4 ). In accordance with the solvent effect of THF noted earlier (Table 1, entry 5), THF prevented cyclization (entry 4).

The uncyclized compounds $\mathbf{4 b}, \mathbf{4 c}, \mathbf{4 f}, \mathbf{7 a}$ and $\mathbf{7 b}$ were then treated with a catalytic amount of NaOEt in EtOH at room temperature (Scheme 5). The reactions of $\mathbf{4 b}, \mathbf{7} \mathbf{a}$ and $\mathbf{7 b}$ proceeded in excellent yields affording diastereomerically pure cyclized products. Unexpectedly, the yield of the vinylcyclopropane $\mathbf{5 c}$ was relatively low. The cyclopropane $\mathbf{5 c}$ isolated was dominantly rich of a single isomer, which was recomfirmed by ${ }^{13} \mathrm{C}$ NMR spectroscopy. This isomer showed a significant N.O.E. between $\mathrm{H}-2$ and $\mathrm{H}-3$, establishing the 2,3-cisconfiguration (cis/trans ratio 90:10). The cyclization reactions of $\mathbf{4 b}, \mathbf{7 a}$ and $\mathbf{7 b}$ gave exclusively single isomers. These results indicate that $4 \mathbf{b}, 7 \mathbf{a}$ and $7 \mathbf{b}$ are highly rich of one type of diastereomers. Surprisingly, compound $\mathbf{4 f}$ derived from $\mathbf{3 a}$ and sodium thiophenoxide did not give any cyclization when treated with $\mathrm{NaOEt}$ in $\mathrm{EtOH}$.

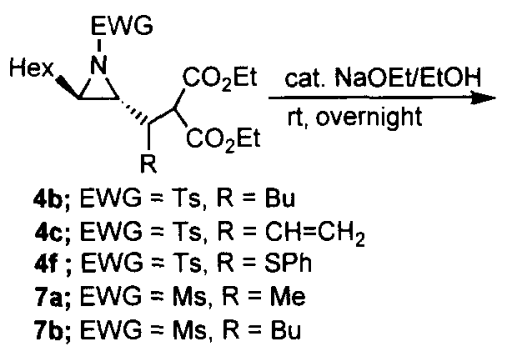

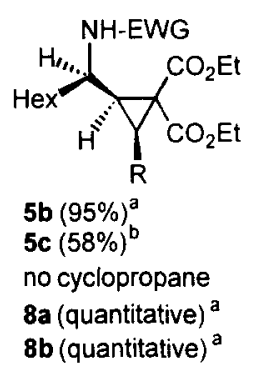

Scheme 5

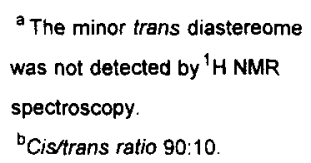

Reactions of aziridine derivatives $3 c, 3 d$ and $3 e$. In order to investigate further the steric influence of substituents on the reaction of the aziridine rings, reactions of $\mathbf{3 a}, \mathbf{3 c}, \mathbf{3 d}$ and $3 \mathbf{e}$ with Grignard reagents in the presence of $10 \mathrm{~mol} \% \mathrm{CuCN}$ were examined (Table 3). When 3-methyl-1-tosyl-aziridine derivative 3c was treated with $\mathrm{BuMgBr} / \mathrm{CuCN}$, the cyclopropane derivative 10 was obtained in $51 \%$ yield with a stereoselectivity of $85: 15$. Under the reaction conditions, the aziridine ring-opened compound $\mathbf{1 1}$ was also obtained ( $21 \%$ yield). ${ }^{18}$

When the 1-(mesitylsulfonyl)-3-methyl-aziridine derivative 3d was subjected to the MIRC reaction with the $\mathrm{MeMgI} / \mathrm{CuCN}$ reagent, a Me group was transferred to give product 12 in $46 \%$ yield; the diastereomer ratio was 40:60 (entry 4). This stereoselectivity is not substantially different from that observed for 3a (entry 1). The steric effect of the mesitylsulfonyl group may be reduced by sulfonamide inversion (vide infra). $\mathrm{BuMgBr} / \mathrm{CuCN}$ similarly gave the desired cyclopropane 13 in $48 \%$ yield with high diastereoselectivity (diastereomeric ratio 91:9). In these reactions, no aziridine ring-opened compounds, such as 11, were detected. ${ }^{18}$ The modest yields obtained from $\mathbf{3 c}$ and $\mathbf{3 d}$ are possibly due to decomposition of the aziridines since they were consumed totally during the course of the reactions.

3-Hexyl-1-(mesitylsulfonyl)-aziridine $\mathbf{3 e}$, which bears large substituents on both the aziridine nitrogen and the aziridine $\mathrm{C}-3$ atom, produced a cyclopropane derivative with high stereoselectivity. It is especially noteworthy that the methyl substituted cyclopropane derivative 14 was obtained with an exceptionally high 
diastereoselectivity (79:21) considering a methyl transfer had occurred. The diastereoselectivity for the introduction of a butyl group (entry 6) was the same as that found for compound 13.

Table 3. Reactions of aziridinyl-methylenemalonates $3 \mathbf{c}-3 \mathbf{e}$ with Grignard reagents catalyzed by $\mathrm{CuCN}$

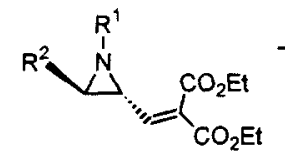

3

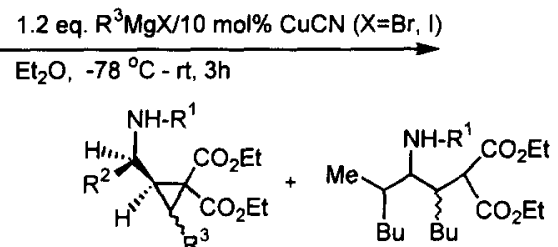

$5 a, 10,12-15$
$11 ; R^{1}=$ Ts $(21 \%$ for $3 c$ only $)$

\begin{tabular}{|c|c|c|c|c|c|c|c|}
\hline Entry & Aziridine & $R^{1}$ & $\mathrm{R}^{2}$ & $\mathrm{R}^{3}$ & Cyclopropane & Yield $(\%)$ & Cis/trans ratio \\
\hline 1 & $3 \mathbf{a}$ & Ts & Hex & $\mathrm{Me}$ & $5 \mathbf{a}$ & 97 & $60: 40$ \\
\hline 2 & $3 \mathbf{a}$ & Ts & Hex & $\mathrm{Bu}$ & $5 b$ & 91 & $85: 15^{a}$ \\
\hline 3 & $3 c$ & Ts & $\mathrm{Me}$ & $\mathrm{Bu}$ & 10 & 51 & $85: 15$ \\
\hline 4 & 3d & $\mathrm{SO}_{2}-2,4,6-\left(\mathrm{CH}_{3}\right)_{3} \mathrm{C}_{6} \mathrm{H}_{2}$ & $\mathrm{Me}$ & $\mathrm{Me}$ & 12 & 46 & $40: 60$ \\
\hline 5 & 3d & $\mathrm{SO}_{2}-2,4,6-\left(\mathrm{CH}_{3}\right)_{3} \mathrm{C}_{6} \mathrm{H}_{2}$ & $\mathrm{Me}$ & $\mathrm{Bu}$ & 13 & 48 & $91: 9$ \\
\hline 6 & 30 & $\mathrm{SO}_{2}-2,4,6-\left(\mathrm{CH}_{3}\right)_{3} \mathrm{C}_{6} \mathrm{H}_{2}$ & Hex & $\mathrm{Me}$ & 14 & 60 & $79: 21$ \\
\hline 7 & $3 e$ & $\mathrm{SO}_{2}-2,4,6-\left(\mathrm{CH}_{3}\right)_{3} \mathrm{C}_{6} \mathrm{H}_{2}$ & Hex & $\mathrm{Bu}$ & 15 & 69 & $90: 10$ \\
\hline
\end{tabular}

a This is the same experiment as shown in Table 1 , entry 6.

Stereochemistry. The ${ }^{1} \mathrm{H}$ NMR spectra of the diastereomerically pure cyclopropane derivatives $\mathbf{5 b}, \mathbf{8 a}, \mathbf{8 b}$ and 15 unfortunately exhibited a complicate coupling pattern and it has not been possible so far to assign the configurations at the cyclopropane $\mathrm{C}-3$ atom. The coupling constants $(\mathrm{J} H-2, \mathrm{H}-3)$ of single-diastereomer-rich (90:10) cyclopropanes 5c and 5d was $9.7 \mathrm{~Hz}$. Braun ${ }^{19}$ observed coupling constants of $7.5 \mathrm{~Hz}$ for transvinylcyclopropane and $9.0 \mathrm{~Hz}$ for the corresponding cis isomer. Kasatkin et al. ' observed a $5 \mathrm{~Hz}$ coupling for the trans isomers and $8 \mathrm{~Hz}$ for the cis isomers (cf. Scheme 1). The vinylcyclopropane 5c was convincingly shown to have a 2,3-cis -configuration by NOE measurement, and the cyclopropane $\mathbf{5 d}$ was therefore assigned to have the 2,3-cis -configuration also.

The chemical shift pattern of all major diastereomers of $5 \mathbf{b}-\mathbf{e}, \mathbf{8 a}, \mathbf{8 b}, \mathbf{1 0}, \mathbf{1 3}, \mathbf{1 4}$, and 15 are very similar, which suggests that they all have the same relative configuration about the $\mathrm{C}-3$ atom. Assuming this is valid, we tentatively assigned the relative configuration at the $\mathrm{C}-3$ atom of the major cyclopropane diastereomers as cis, because the C-3 configuration of the vinylcyclopropane $5 \mathbf{c}$ was determined to be cis (vide supra). It was anticipated that the consideration of the transition state of the conjugate addition reaction might provide a support for the assignment.

When the $N$-substituent of the aziridine ring was altered from tosyl to the mesitylsulfonyl group, there was an increase of the degree of the cis/trans ratio (Table 3, compare entries 1, 2, 3 with entries 6, 7, 5 respectively). This effect was not observed when the tosyl group was changed for the mesyl group (Table 2); the degrees of the cis/trans ratio's during the reactions of the two types of $N$-substituents were observed to be essentially identical. It is very noteworthy that the mesitylsulfonyl group provided the 79:21 cis/trans ratio during the reaction of the aziridine $3 \mathbf{e}$ and methylmagnesium iodide (Table 3, entry 6) but the mesyl group produced a 1:1 mixture of the methylcyclopropane derivatives (Table 2, entry 1).

Yamamoto et al. studied the diastereoselectivity of the conjugate addition of organocuprate reagents to $\gamma$ alkoxy $\alpha, \beta$-unsaturated diester derivatives. ${ }^{9}$ They discussed whether a powerful Michael acceptor having a high electron-accepting ability or a reactive copper reagent having a high electron-donating ability is prone to 
produce a $\pi$-complex (Figure 1). When the $\gamma$-t-butyldimethylsilyloxy (TBDMS) containing Michael acceptors ( $\mathrm{R}^{\prime}=\mathrm{TBDMS}$; the TBDMS is a "non-chelating" group), reacted with organocopper reagents, the steric bulk difference between $R$ and $R$ ' determined the outcome. The electron-deficient nitrogen atom of the aziridines may be assumed to be comparatively non-chelating as is the oxygen atom of the tert-butyldimethylsilyloxy group. If this Yamamoto's approach is applied to the aziridinyl-substituted Michael acceptors described here, the conjugate reactions could occur through the transition state model shown in Figure 2. In this model, the preferred conformation arising from rotation about the single bond between the aziridinyl C-2 atom and the olefinic carbon is incorporated. The model is presented as a Newman projection viewed along this bond. The 1,3 -allylic strain theory ${ }^{20}$ supports this configuration in which the hydrogen atom on the aziridine $\mathrm{C}-2$ is positioned inside. Another relevant aspect is the relative position of the C-3 substituent and the $\mathrm{N}$-arylsulfonyl group. It is presumed that the steric effect is more influential than the bond-orbital effect. ${ }^{21}$ Molecular models show considerable differences of the steric environment around $\mathrm{C}-3$ and sulfonamide group when this group inverts. The preponderant conformational isomer of 3 with respect to the sulfonamide group is likely to be the one where the C-3 alkyl group and the $N$-sulfonyl group are positioned on opposite sides of the aziridine ring and the sulfonyl group covers the upper side of the methylene double bond. The largest group on the aziridine of this isomer is the sulfonamide group, which is assumed to occupy the anti position in the model with $\mathrm{C}-3$ on the outside position, as shown in Figure 2. In the alternative minor aziridine invertomer, the C-3 alkyl substituent and the $\mathrm{N}$-sulfonyl group are positioned on the same side. Thus, the sulfonyl group does not shield the double bond and the aziridine C-3 substituent is now the largest group and located in an anti position. Nucleophilic attack at the Michael acceptor can take place from both sides of the double bond when there is no shielding effect. Attack from the upper side should produce the 2,3-trans-cyclopropane whereas the 2,3-ciscyclopropane should result by attack at the alternative lower face. By taking into account that in the preferred conformation (as shown in Figure 2) the upper face is shielded by the $\mathrm{N}$-sulfonyl group, the formation of the $c$ is product is favored.

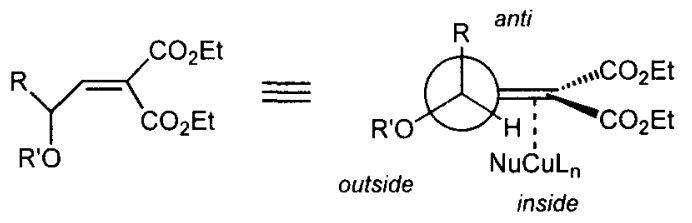

Figure 1. Yamamoto's model

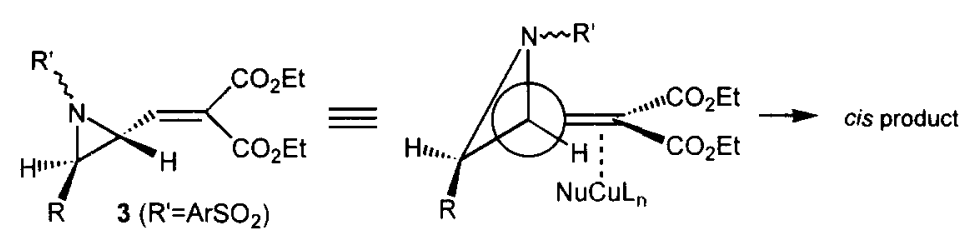

Figure 2. A model for the preferred conformation of aziridine 3

Some information about the inversion of the nitrogen atom in these aziridine derivatives was obtained from temperature dependent ${ }^{1} \mathrm{H}$ NMR measurements. At a temperature of $-63^{\circ} \mathrm{C}$, the $\mathrm{H}-3$ aziridine ring proton of 3a shows up as two signals in the ratio of 70:30. Although the exact reaction temperature at which the conjugate addition occurs is not clear, this NMR analysis is consistent with the experimental result. Since $30 \%$ 
of the aziridine 3a seems to possess the conformation with the tosyl group on the side opposite to the unsaturated diester moiety, conjugate addition of nucleophiles can occur equally well from both sides of the double bond leading therefore to the 50:50 ratio. Meanwhile, the other conformer (70\%) allows nucleophiles to approach from only one side of the double bond. This results in 85:15 cis/trans ratio observed during the reaction with $\mathrm{BuMgBr}$.

The transition state model shown in Figure 2 indicates that the variation of substituents at the aziridine C3 position (methyl or hexyl) would probably have only a slight effect on the diastereoselectivity, because the steric environment around the aziridine C-3 is less crowded than that around the nitrogen of the tosylamido group due to the trans-configuration. Nucleophilic approach should be preferred from the bottom side leading to 2,3-cis-cyclopropane (reactions of 3a-c). The size of this $\mathrm{C}-3$ substituent may influence however the ratio of the aziridine invertomers; the smaller the substituent the more this ratio shifts to $1: 1$, and therefore the size of the C-3 substituent will indirectly affect the shielding of the upper face of the Michael acceptor. The experiments of the substrates $3 \mathrm{a}$ and $\mathbf{3 c}$ with $\mathrm{BuMgBr} / \mathrm{CuCN}$ as the reagent showed no significant difference in the cis/trans ratio. The reaction of $\mathrm{MeMgI/CuCN}$ with $3 \mathbf{d}$ showed a lower diastereoselectivity. Apparently, the sterically hindered mesitylsulfonyl group does not shield the upper side of the unsaturated diester moiety sufficiently to prevent attack by the small nucleophile from the upper face. This result supports the supposition that the conformational preference of this substrate is less outspoken, presumably because the small C-3 substituent (methyl) has only little effect on the ratio of the sulfonamide invertomers (almost 1:1 ratio) and therefore diminishing the shielding over the Michael acceptor. In contrast substrate $3 e$ which has a larger hexyl group at C-3 shows a much higher diastereoselectivity (Table 3, entry 6) in its reaction with the $\mathrm{MeMgl} / \mathrm{CuCN}$ reagent. Clearly, the preponderant conformational isomer in Figure 2 is now much more predominant due to the steric repulsion between the large mesitylsulfonyl group and the C-3 (hexyl) group when compared with 3c, implying that in $3 \mathbf{e}$ the mesitylsulfonyl group exerts an effective shielding effect on the olefinic moiety which results in a high diastereoselectivity. When the more bulky reagent $\mathrm{BuMgBr} / \mathrm{CuCN}$ is used in these MIRC reactions, invariably excellent diastereoselectivity was achieved (Table 3 , entries $2,3,5$ and 7 ). This result is readily explained as the sterically demanding reagent will be more sensitive to steric constraint in the substrate, meaning that the least hindered pathway will be followed in the course of the approach of nucleophiles.

In order to gain further support for the proposed transition state model, cis aziridine derivative $\mathbf{1 6}$ was subjected to the MIRC reaction (Scheme 6).

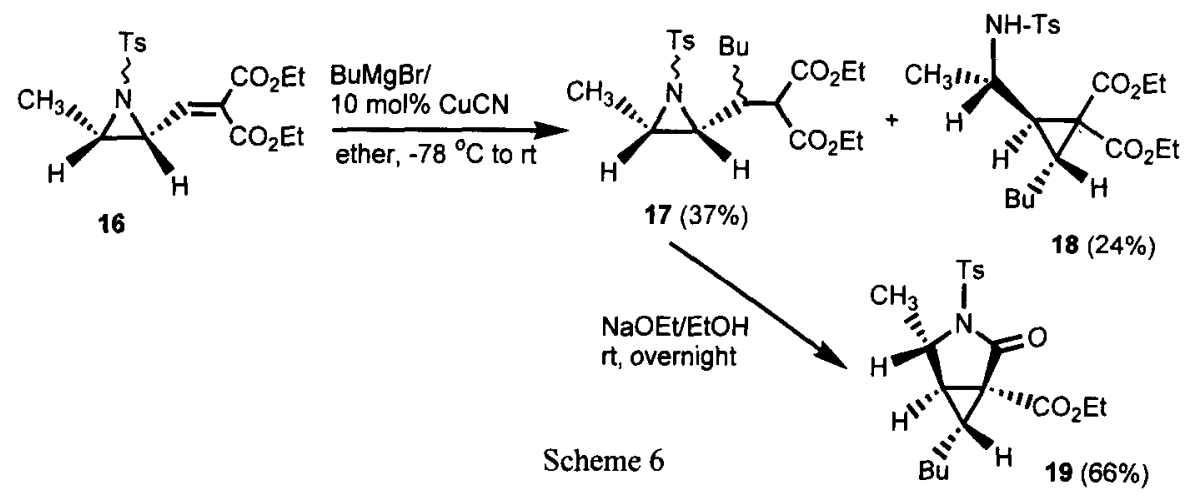

This substrate molecule was conveniently prepared from threonine (see the Experimental Section). Aziridine 16 reacted with $\mathrm{BuMgBr} / \mathrm{CuCN}$ to yield the cyclopropanedicarboxylate 18 in $24 \%$ yield. The ${ }^{1} \mathrm{H}$ 
NMR chemical shift pattern suggested that the configuration of 18 was 2,3-trans. The uncyclized product 17 was also obtained in a considerable amount (37\%). Compound 17 was converted to compound 19 on treatment with $\mathrm{NaOEt} / \mathrm{EtOH}$ overnight at room temperature. Cyclization under the last-mentioned conditions was followed by a lactamization reaction which was not observed for the trans-aziridine substrates.

The formation of the trans-cyclopropane product 18 can be explained by adopting the same approach as for the trans-aziridine 3 . The preferred conformation of $\mathbf{1 6}$ leading to the transition state is strongly governed by the 2,3-cis configuration of the C-3 methyl group and the olefinic moiety. This cis relationship forces the $N$ tosyl group on the side opposite to both the C-3 methyl group and the olefinic moiety. The shielding effect on the Michael acceptor, therefore, will not be as effective as in the substrate $3 \mathbf{c}$. The configuration of the aziridine $\mathrm{C}-3$ of $\mathbf{1 6}$ is opposite to that of $\mathbf{3 c}$ and inspection of molecular models suggests that the preferred conformation can be pictured as shown in Figure 3, whereby the methyl group is shielding the bottom side. As a consequence the nucleophilic reagent, $\mathrm{BuMgBr} / \mathrm{CuCN}$, is primarily directed toward the upper face of the Michael acceptor.

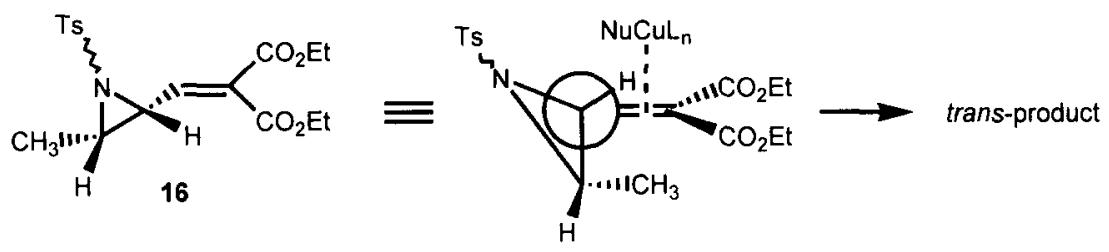

Figure 3. Newman projection of the preferred conformation of aziridine $\mathbf{1 6}$

The amount of uncyclized product $\mathbf{1 7}$ formed during the reaction of $\mathbf{1 6}$ with the Grignard reagent is too large to be ignored. The trans-cyclopropane in this case seems to be formed reluctantly. The explanation for this reluctance is not yet known.

Reactions with Hetero-Organocuprate Reagents. During the discussion of the results presented in Table 3 (vide supra), it was indicated that more sterically demanding nucleophilic reagents increase the diastereoselectivity of the MIRC reaction. Further elaboration of this observation leads to the suggestion that better diastereoselectivity may be obtained when copper reagents with a large "dummy" volume are employed. Hetero-organocuprates possibly provide such a "dummy" volume. The non-transferable group R' in RR'CuM with $\mathrm{M}$ being $\mathrm{Li}$ or $\mathrm{MgBr}$ can be residues derived from alcohols, thiols, amines or alkynes. The effect of nontransferable R' group on the MIRC reaction was investigated. Grignard reagents were used instead of organo lithium reagents as the source of the transferable $R$ group because of easier availability.

Initially, methyl transfer was implemented with hetero-organocuprates, but attempts based on a common procedure using preformed $\mathrm{MeCu}$ and $\mathrm{R}^{\prime} \mathrm{Li}$ did not give cyclopropanes. It is known that the extent of stereoselectivity of organocuprate reagents is influenced by various factors such as the structure of the substrate, solvent, concentration of reagents, presence of salts and the reaction temperature. ${ }^{22}$ The sequence of addition was inversed with $\mathrm{MeMgBr}$ being added to the preformed $\mathrm{R}^{\prime} \mathrm{Cu}$ (Table 4). The $\mathrm{R}^{\prime} \mathrm{Cu}$ compounds were conveniently prepared by addition of an etherial solution of R'Li to an etherial suspension of Cul. The use of two equivalents of $\mathrm{MeMgBr}$ is essential for achieving the desired conjugate addition. The use of only one equivalent of the Grignard reagent resulted in recovery of unchanged 3a (entry 2). 
The results shown in Table 4 indicate that indeed the diastereoselectivity of the MIRC reaction improves as the steric bulk of $R^{\prime}$ increased. The combination of diisopropylamine and diethyl ether (entry 7) resulted in a high reaction yield and a high diastereoselectivity, but a lower chemical yield with higher diastereoselectivity was observed using dimethyl sulfide as solvent (entry 6). The chemical yield and diastereoselectivity was most satisfactory using (-)-terpinen-4-ol (entry 5).

In the set-up of the experiments collected in Table 3, the mesitylsulfonyl group was selected as the second aziridine activating function with the objective to improve the diastereofacial selectivity during the conjugate addition. It was therefore surprising that reactions of 1-(mesitylsulfonyl)-aziridine derivative $\mathbf{3 e}$ with heteroorganocuprates involving the use of diisopropylamine and terpinenol resulted in diastereomer ratio's ranging from $67: 33$ to $80: 20$. The diastereoselectivity even varied under the same reaction conditions. Although no clear answer is yet available for this observation, the following explanation is proposed.

In the preferred configuration (Figure 2) leading to the transition state where the $N$-arylsulfonyl group shields the olefinic moiety, the bulky mesitylsulfonyl group of 3e provokes more serious repulsion with the olefinic moiety. The mesitylsulfonyl group, therefore, cannot sustain the anti position and rotates slightly outside to ease the repulsion (Figure 4). This rotation at the same time means the move of the C-3 hexyl group of the aziridine toward the anti position. But when the hexyl group occupies the anti position, there will be much less space for the nucleophilic reagents to form a $\pi$-complex from the lower face of the olefinic moiety in Figure 4. Because of this rotation, the voluminous hetero-organocuprates do not experience an energetic

Table 4. Reactions of $3 \mathbf{a}$ with hetero-organocuprate reagents

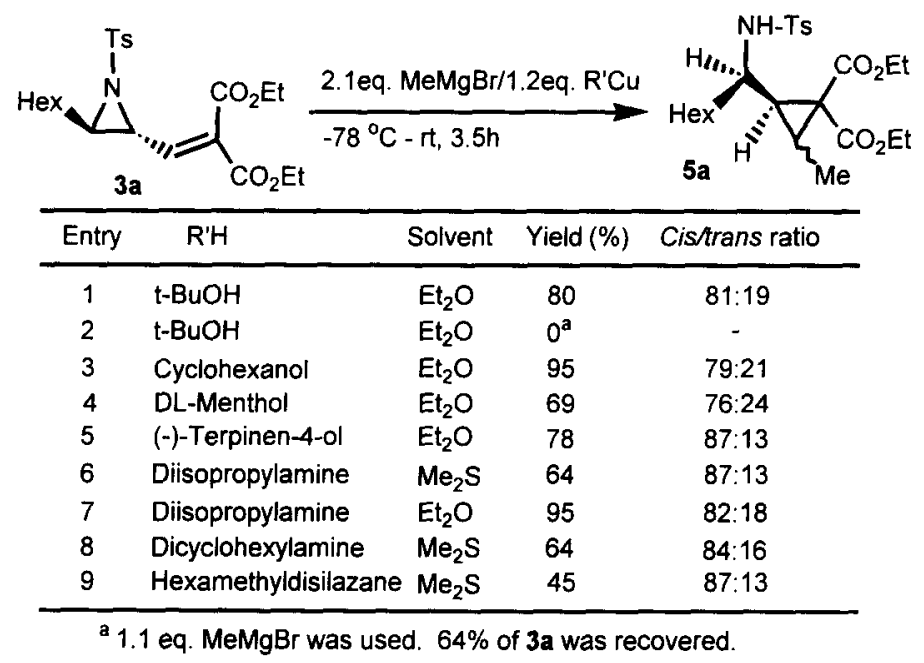

advantage during the attack from the lower side of the olefinic moiety. Meanwhile, since one extra equivalent of $\mathrm{MeMgBr}$ is present (and required), certain amount of uncomplexed Grignard reagent may well exist in equilibrium with the organocuprate complex. These free species may be able to approach the upper face and the lower face of the Michael acceptor with comparable ease. 


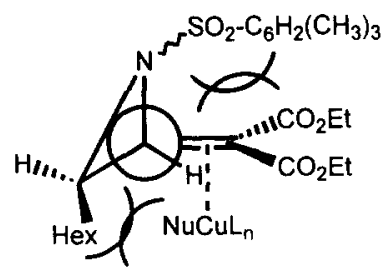

Figure 4. A model for the preferred conformation of aziridine $\mathbf{3 e}$

\section{CONCLUSIONS}

The occurrence of Michael-reaction Initiated Ring Closure (MIRC) reactions of aziridinylmethylenemalonates 3 and $\mathbf{1 6}$ has been established. A variety of substituents could be introduced onto the resulting cyclopropane dicarboxylic ester derivatives with a highly diastereoselective formation of the cisisomer (cis:trans ratio's ranged from 50:50 to 91:9). Conjugate addition to the methylenemalonate moiety was much more favorable than direct aziridine ring opening due to the presence of the activating malonate system. Grignard reactions catalyzed by $\mathrm{CuCN}$ appeared to be the most promising because clean reactions with a high degree of diastereoselectivity were achieved. Even the small methyl group was introduced with a relatively high diastereoselectivity (cis:trans ratio of $87: 13$ ).

It is of interest to note that the preference for the formation of the cis-cyclopropane derivatives is opposite to that observed by Kasatkin ${ }^{16}$ during the MIRC reaction of the epoxide analogue. This difference can be attributed to the influence of the arylsulfonyl group at the aziridine nitrogen atom on the preferred conformation of the substrate 3 in the transition state. In this conformation, one face of the Michael acceptor is effectively shielded by the $N$-arylsulfonyl group implying a selective approach of the nucleophilic reagent to the other face of the double bond moiety. For the substrate 16 which has a cis-substituted aziridine ring, the formation of trans-cyclopropane derivatives is predominant. This stereochemical course could be explained similarly by invoking the preferred conformation leading to the transition state.

The results obtained suggest that steric interactions between the nucleophilic reagent and the substituents of the three-membered heterocyclic ring are of importance in governing the stereochemical outcome. Moreover, the stoichiometry and the sequence of addition of hetero-organocuprates play a significant role.

\section{EXPERIMENTAL SECTION}

Proton and ${ }^{13} \mathrm{C}$ magnetic resonance spectra were measured on a Bruker $\mathrm{AC}-100$ or a Bruker $\mathrm{AM}-400$ spectrometer. Chemical shift values are reported as $\delta$-values relative to tetramethylsilane as an internal standard. Mass spectra were obtained with a double focussing VG 7070E spectrometer. IR spectra were recorded on a Perkin-Elmer 298 infrared spectrophotometer. Melting points were measured with a Reichert Thermopan microscope and are uncorrected. Recrystallizations were carried out using hexane-EtOAc unless stated otherwise. GLC was conducted with a Hewlett-Packard HP 5890 gas chromatograph, using a capillary column $(25 \mathrm{~m})$ of $\mathrm{HP}-1$, and nitrogen at $2 \mathrm{ml} / \mathrm{min}(0.5 \mathrm{~atm})$ as the carrier gas. Commercial $\mathrm{n}$-BuLi solution in hexane (ca. $1.6 \mathrm{M}$ ) was purchased from Merck. $\mathrm{MeMgBr}\left(3.0 \mathrm{M}\right.$ in $\left.\mathrm{Et}_{2} \mathrm{O}\right)$ was purchased from Aldrich Chemical $\mathrm{Co}$. and was diluted with $\mathrm{Et}_{2} \mathrm{O}$ to make a $1.0 \mathrm{M}$ solution. (Vinyl) $\mathrm{MgBr}(1.0 \mathrm{M}$ in tetrahydrofuran) was also purchased from Aldrich Chemical Co. tert-Butyl alcohol, hexane and dimethyl sulfide were distilled from calcium hydride, and menthol was recrystallized from pet.-ether (60-80), and other alcohols, cyclohexanol 
and terpineol were simply distilled before use. All amines for hetero-organocuprates, i.e. diisopropylamine, dicyclohexylamine and hexamethyldisilazane were distilled over calcium hydride under Ar prior to use. Diethyl ether was pre-dried over calcium chloride, then distilled from calcium hydride and again from sodium hydride. Tetrahydrofuran was freshly distilled from lithium aluminumhydride. All other solvents were obtained commercially and used unpurified. Thin-layer chromatography (TLC) was performed on silica gel F-254 plates (thickness $0.25 \mathrm{~mm}$ ). Spots were visualized with a UV hand lamp, $\mathrm{K}_{2} \mathrm{Cr}_{2} \mathrm{O}_{7}$ solution in dil. $\mathrm{H}_{2} \mathrm{SO}_{4}$ or $\mathrm{Cl}_{2}$ TDM ${ }^{23}$ Column chromatography was performed using silica $60 \mathrm{H}$ (for flash chromatography, Merck, art. nr. 7736) or silica 60 (Merck, art. nr. 7734).

trans-2-Formyl-3-hexyl-aziridine derivatives: The synthesis of trans-2-formyl-3-hexyl-1-(toluene-4sulfonyl)-aziridine $\mathbf{2 a}$ is representative. A hexane solution of diisobutylaluminumhydride (1.0 M, $2.7 \mathrm{~mL}, 2.7$ mmol) was added to a cooled $\left(-78{ }^{\circ} \mathrm{C}\right)$ solution of ethyl trans-3-hexyl-1-(toluene-4-sulfonyl)-aziridine-2carboxylate $1 \mathrm{a}(0.80 \mathrm{~g}, 2.3 \mathrm{mmol})$ in dichloromethane $(11 \mathrm{~mL})$ under Ar. On completion of the addition, the mixture was stirred for a further one hour when a solution of sodium fluoride $(0.94 \mathrm{~g})$ in water $(0.72 \mathrm{~mL})$ was added. The reaction mixture was allowed to warm slowly to room temperature and the white solid thus obtained was collected. The filtrate was concentrated in vacuo and column chromatography (hexane-EtOAc (4:1)) of the residual oil afforded trans-2-formyl-3-hexyl-1-(toluene-4-sulfonyl)-aziridine $2 \mathrm{a}(0.60 \mathrm{~g}, 1.9 \mathrm{mmol})$ in $84 \%$ yield.

trans-2-Formyl-3-hexyl-1-(toluene-4-sulfonyl)-aziridine (2a). Oil; IR $\left(\mathrm{CCl}_{4}\right)$ 2920, 1718, 1450, 1340 $\mathrm{cm}^{-1}$; ${ }^{1} \mathrm{H}$ NMR $\left(\mathrm{CDCl}_{3}\right) \delta$ 0.78-0.98 (m, 3H, $\left.\mathrm{CH}_{3} \mathrm{CH}_{2}\right), 1.08-1.85\left(\mathrm{~m}, 10 \mathrm{H}, \mathrm{CH}_{3}\left(\mathrm{CH}_{2}\right)_{5}\right), 2.46\left(\mathrm{~s}, 3 \mathrm{H}, \mathrm{C}_{6} \mathrm{H}_{4} \mathrm{CH}_{3}\right)$, $3.08(\mathrm{dd}, \mathrm{J}=3.3,6.7 \mathrm{~Hz}, 1 \mathrm{H}, \mathrm{NCHCHO}), 3.25-3.45(\mathrm{~m}, 1 \mathrm{H}, \mathrm{HexC} H \mathrm{~N}), 7.38\left(\mathrm{~d}, \mathrm{~J}=9.4 \mathrm{~Hz}, 2 \mathrm{H}, 3,5-\mathrm{C}_{6} H_{4}\right)$, $7.86\left(\mathrm{~d}, \mathrm{~J}=9.4 \mathrm{~Hz}, 2 \mathrm{H}, 2,6-\mathrm{C}_{6} H_{4}\right), 9.44(\mathrm{~d}, \mathrm{~J}=6.6 \mathrm{~Hz}, 1 \mathrm{H}, \mathrm{CHO})$; HRMS $(\mathrm{M}+1)^{+}$; Calcd for $\mathrm{C}_{16} \mathrm{H}_{24} \mathrm{NO}_{3} \mathrm{~S}$ : 310.14769 ; Found: 310.14759 amu.

trans-2-Formyl-3-hexyl-1-methylsulfonyl-aziridine (2b). $86 \%$ yield; $\mathbf{2} \mathbf{b}$ was obtained as an oil in a similar manner; ${ }^{1} \mathrm{H}$ NMR $\left(\mathrm{CDCl}_{3}\right) \delta$ 0.78-1.01 (m, 3H, $\left.\mathrm{CH}_{3} \mathrm{CH}_{2}\right), 1.01-1.92\left(\mathrm{~m}, 10 \mathrm{H}, \mathrm{CH}_{3}\left(\mathrm{CH}_{2}\right)_{5}\right), 3.03-3.20$ $\left(\mathrm{m}+\mathrm{s}, 4 \mathrm{H}, \mathrm{SO}_{2} \mathrm{CH}_{3}, \mathrm{CH}_{2} \mathrm{CHN}\right), 3.22-3.44(\mathrm{~m}, 1 \mathrm{H}, \mathrm{NCHCHO}), 9.33(\mathrm{~d}, \mathrm{~J}=6.7 \mathrm{~Hz}, 1 \mathrm{H}, \mathrm{CHO})$; HRMS $(\mathrm{M}+1)^{+}$; Calcd for $\mathrm{C}_{10} \mathrm{H}_{20} \mathrm{NO}_{3} \mathrm{~S}: 234.11639$; Found: $234.11641 \mathrm{amu}$.

Ethyl 3-methyl-1-(2,4,6-trimethylbenzenesulfonyl)-aziridin-2-carboxylate. A stirred cooled $\left(0{ }^{\circ} \mathrm{C}\right)$ solution of ethyl 3-methyl-aziridin-2-carboxylate $(0.70 \mathrm{~g}, 5.4 \mathrm{mmol}), \mathrm{Et}_{3} \mathrm{~N}(1.5 \mathrm{~mL}, 11 \mathrm{mmol})$ and a small catalytic amount of DMAP in $\mathrm{CH}_{2} \mathrm{Cl}_{2}(50 \mathrm{~mL})$ maintained under $\mathrm{Ar}$ was treated with mesitylenesulfonyl chloride $(1.5 \mathrm{~g}, 6.5 \mathrm{mmol})$. The mixture was stirred at $0{ }^{\circ} \mathrm{C}$ for $30 \mathrm{~min}$ and then at room temperature for 2 days, whereon it was treated with saturated aqueous $\mathrm{NH}_{4} \mathrm{Cl}(50 \mathrm{~mL})$ and extracted with $\mathrm{CH}_{2} \mathrm{Cl}_{2}(3 \times 30 \mathrm{~mL})$. The combined organic extracts were washed with brine, dried $\left(\mathrm{MgSO}_{4}\right)$ and concentrated in vacuo. Column chromatography (hexane-EtOAc (7:1)) of the residue gave the $N$-(2,4,6-trimethylbenzenesulfonyl)-aziridine derivative as an oil $\left(0.89 \mathrm{~g}, 53 \%\right.$ yield). IR $\left(\mathrm{CCl}_{4}\right) 2980,1750,1600,1510,1330,1240 \mathrm{~cm}^{-1}$; ${ }^{1} \mathrm{H} \mathrm{NMR}\left(\mathrm{CDCl}_{3}\right)$ $\delta 1.21\left(\mathrm{t}, \mathrm{J}=7.2 \mathrm{~Hz}, 3 \mathrm{H}, \mathrm{OCH}_{2} \mathrm{CH}_{3}\right), 1.71\left(\mathrm{~d}, \mathrm{~J}=5.9 \mathrm{~Hz}, 3 \mathrm{H}, \mathrm{CH}_{3} \mathrm{CHN}\right), 2.30\left(\mathrm{~s}, 3 \mathrm{H}, 4-\mathrm{CH}_{3}-\mathrm{C}_{6} \mathrm{H}_{2}\right), 2.70(\mathrm{~s}$, $\left.6 \mathrm{H}, 2,6-\left(\mathrm{CH}_{3}\right)_{2} \mathrm{C}_{6} \mathrm{H}_{2}\right), 3.02-3.23\left(\mathrm{~m}, 1 \mathrm{H}, \mathrm{CH}_{3} \mathrm{CHN}\right), 3.32(\mathrm{~d}, \mathrm{~J}=3.9 \mathrm{~Hz}, 1 \mathrm{H}, \mathrm{NCHCO} 2 \mathrm{Et}), 4.13$ (q, J $=7.1 \mathrm{~Hz}$, $\left.2 \mathrm{H}, \mathrm{OCH}_{2} \mathrm{CH}_{3}\right), 6.94$ (s, 2H, 3, 5- $\mathrm{C}_{6} H_{2}$ ); $\mathrm{MS}(\mathrm{EI}): \mathrm{m} / \mathrm{e}$ (relative intensity (\%)) $311(\mathrm{M}, 32), 266(3.0), 238(7.5)$, $174(31), 128(54), 119(100), 100(100)$. 
trans-2-Formyl-3-methyl-1-(2,4,6-trimethylbenzenesulfonyl)-aziridine (2d). 91\% yield; 2d was obtained as an oil in a similar manner starting from ethyl 3-methyl-1-(2,4,6-trimethylbenzenesulfonyl)-aziridin2-carboxylate; IR $\left(\mathrm{CCl}_{4}\right) 2940,1720,1600,1450,1400,1330,1165 \mathrm{~cm}^{-1} ;{ }^{1} \mathrm{H} \mathrm{NMR}\left(\mathrm{CDCl}_{3}\right) \delta 1.51(\mathrm{~d}, \mathrm{~J}=5.7$ $\mathrm{Hz}, 3 \mathrm{H}, \mathrm{CH}_{3} \mathrm{CHN}$ ), 2.32 (s, 3H, 4- $\left.\mathrm{CH}_{3} \mathrm{C}_{6} \mathrm{H}_{2}\right), 2.68\left(\mathrm{~s}, 6 \mathrm{H}, 2,6-\left(\mathrm{CH}_{3}\right)_{2} \mathrm{C}_{6} \mathrm{H}_{2}\right), 3.12$ (dd, J = 3.8, 6.7 Hz, $1 \mathrm{H}$, $\mathrm{NCHCHO}$ ), 3.32-3.54 (m, 1H, $\left.\mathrm{CH}_{3} \mathrm{CHN}\right), 6.98\left(\mathrm{~s}, 2 \mathrm{H}, 3,5-\mathrm{C}_{6} \mathrm{H}_{2}\right), 9.31$ (d, J = 6.7 Hz, 1H, CHO); MS (EI): $\mathrm{m} / \mathrm{e}$ (relative intensity (\%)) $267(\mathrm{M}, 15), 174(9.7), 119(100), 84(45)$.

Aziridinyl-methylenemalonate derivatives: The following synthesis of diethyl [3-hexyl-1-(toluene-4sulfonyl)-aziridin-2-ylmethylene]-malonate 3a is representative. Dry THF (15 mL) was placed in a 50 -mL flask and kept under $\mathrm{Ar}$ at $0{ }^{\circ} \mathrm{C} ; \mathrm{TiCl}_{4}(0.33 \mathrm{~mL}, 3.0 \mathrm{mmol})$ was added with a syringe to give a yellow suspension. Diethyl malonate $(0.22 \mathrm{~mL}, 1.5 \mathrm{mmol})$ and then 2-formyl-3-hexyl-1-(toluene-4-sulfonyl)-aziridine $(0.45 \mathrm{~g} .1 .5$ $\mathrm{mmol}$ ) each dissolved in dry THF $(5 \mathrm{~mL})$ were added and successively, followed by pyridine $(0.48 \mathrm{~mL}, 6.0$ $\mathrm{mmol}$ ) to give a deep red-brown solution. The mixture was stirred at room temperature for 3 days, treated with saturated $\mathrm{NH}_{4} \mathrm{Cl}$ aqueous solution $(25 \mathrm{~mL})$ and extracted with ether $(3 \times 25 \mathrm{~mL})$. The combined organic layers were washed with brine, dried $\left(\mathrm{MgSO}_{4}\right)$ and concentrated in vacuo. Column chromatography (hexane-EtOAc $(7: 1))$ of the residue gave $3 \mathrm{a}(0,35 \mathrm{~g}, 7.8 \mathrm{mmol})$ as an oil $(52 \%)$.

2-[3-Hexyl-1-(toluene-4-sulfonyl)-aziridin-2-ylmethylene]-malonic acid diethyl ester (3a). $\mathrm{IR}\left(\mathrm{CCl}_{4}\right)$ 2920, 1720, 1330, 1250, $1160 \mathrm{~cm}^{-1}$; ${ }^{1} \mathrm{H}$ NMR $\left(\mathrm{CDCl}_{3}\right) \delta 0.72-1.0\left(\mathrm{~m}, 3 \mathrm{H}, \mathrm{CH} \mathrm{CH}_{2} \mathrm{CH}_{2}\right), 1.0-1.54(\mathrm{~m}, 14 \mathrm{H}$, $\left.\mathrm{CH}_{3}\left(\mathrm{CH}_{2}\right)_{4}, 2 \times \mathrm{OCH}_{2} \mathrm{CH}_{3}\right), 1.54-1.88\left(\mathrm{~m}, 2 \mathrm{H}, \mathrm{CH}_{2} \mathrm{CHN}\right), 2.44\left(\mathrm{~s}, 3 \mathrm{H}, \mathrm{C}_{6} \mathrm{H}_{4} \mathrm{CH}_{3}\right), 2.90-3.12\left(\mathrm{~m}, 1 \mathrm{H}, \mathrm{CH}_{2} \mathrm{C} / \mathrm{N}\right)$, $3.54($ dd. $\mathrm{J}=4.0,10 \mathrm{~Hz}, 1 \mathrm{H}, \mathrm{NCHCH}=\mathrm{C}), 4.25+4.31\left(2 \mathrm{xq}, \mathrm{J}=7.1 \mathrm{~Hz}, 4 \mathrm{H}, 2 \mathrm{xOCH}_{2} \mathrm{CH}_{3}\right), 6.98(\mathrm{~d}, \mathrm{~J}=10 \mathrm{~Hz}$, $1 \mathrm{H}, \mathrm{CH}=\mathrm{C}), 7.30\left(\mathrm{~d}, \mathrm{~J}=9.4 \mathrm{~Hz}, 2 \mathrm{H}, 3,5-\mathrm{C}_{6} H_{4}\right), 7.82\left(\mathrm{~d}, \mathrm{~J}=9.4 \mathrm{~Hz}, 2 \mathrm{H}, 2,6-\mathrm{C}_{6} H_{4}\right)$; HRMS $(\mathrm{M}+1)^{+}$; Calcd for $\mathrm{C}_{23} \mathrm{H}_{34} \mathrm{NO}_{6} \mathrm{~S}: 452.21069$; Found: $452.21060 \mathrm{amu}$.

2-(3-Hexyl-1-methylsulfonyl-aziridin-2-ylmethylene)-malonic acid diethyl ester (3b). $3 b$ was obtained similarly in $62 \%$ yield as an oil; IR $\left(\mathrm{CCl}_{4}\right) 2920,1730,1465,1330,1150 \mathrm{~cm}^{-1} ;{ }^{1} \mathrm{H} \mathrm{NMR}\left(\mathrm{CDCl}_{3}\right) \delta$ 0.80-1.05 (m, 3H, $\left.\mathrm{CH}_{3} \mathrm{CH}_{2} \mathrm{CH}_{2}\right), 1.15-1.95\left(\mathrm{~m}, 16 \mathrm{H}, \mathrm{CH}_{3}\left(\mathrm{CH}_{2}\right)_{5}, 2 \mathrm{XOCH}_{2} \mathrm{CH}_{3}\right), 2.88-3.1(\mathrm{~m}, 1 \mathrm{H}, \mathrm{HexC} H \mathrm{~N})$, $3.09\left(\mathrm{~s}, 3 \mathrm{H}, \mathrm{SO}_{2} \mathrm{CH}_{3}\right), 3.49(\mathrm{dd}, \mathrm{J}=4.5,10 \mathrm{~Hz}, 1 \mathrm{H}, \mathrm{NCHCH}=\mathrm{C}), 4.26\left(\mathrm{q}, \mathrm{J}=7.1 \mathrm{~Hz}, 2 \mathrm{H}, \mathrm{OCH}_{2} \mathrm{CH}_{3}\right), 4.34(\mathrm{q}$, $\left.J=7.3 \mathrm{~Hz}, 2 \mathrm{H}, \mathrm{OCH}_{2} \mathrm{CH}_{3}\right), 6.77(\mathrm{~d}, \mathrm{~J}=10 \mathrm{~Hz}, 1 \mathrm{H}, \mathrm{CH}=\mathrm{C})$; HRMS $(\mathrm{M}+1)^{+}$; Calcd for $\mathrm{C}_{17} \mathrm{H}_{30} \mathrm{NO}_{6} \mathrm{~S}$ : 376.17938; Found: 376.17939 amu.

2-[3-Methyl-1-(toluene-4-sulfonyl)-aziridin-2-ylmethylene]-malonic acid diethyl ester (3c). Methyl analogue $3 \mathbf{c}$ was prepared as above (cf. 3a) from ethyl 3-methyl-aziridin-2-carboxylate via the $N$-tosyl-aziridine ( $92 \%$ yield), reduction ( $41 \%$ yield) and condensation with diethyl malonate (65\% yield). The product was an oil; ' ${ }^{\mathrm{H}} \mathrm{NMR}\left(\mathrm{CDCl}_{3}\right) \delta 1.20-1.50\left(\mathrm{~m}, 6 \mathrm{H}, 2 \mathrm{xOCH}_{2} \mathrm{CH}_{3}\right), 1.58\left(\mathrm{~d}, \mathrm{~J}=6.0 \mathrm{~Hz}, 3 \mathrm{H}, \mathrm{CH}_{3} \mathrm{CHN}\right), 2.44(\mathrm{~s}, 3 \mathrm{H}$, $\left.\mathrm{C}_{6} \mathrm{H}_{4} \mathrm{C} H_{3}\right), 2.90-3.14\left(\mathrm{~m}, 1 \mathrm{H}, \mathrm{CH}_{3} \mathrm{C} H \mathrm{~N}\right), 3.58(\mathrm{dd}, \mathrm{J}=4.5,10 \mathrm{~Hz}, 1 \mathrm{H}, \mathrm{CHC} H \mathrm{~N}), 4.23+4.33(2 \mathrm{xq}, \mathrm{J}=7.1 \mathrm{~Hz}$, $\left.4 \mathrm{H}, 2 \mathrm{xOCH}_{2} \mathrm{CH}_{3}\right), 6.78(\mathrm{~d}, \mathrm{~J}=9.6 \mathrm{~Hz}, 1 \mathrm{H}, \mathrm{CH}=\mathrm{C}), 7.31\left(\mathrm{~d}, \mathrm{~J}=8.2 \mathrm{~Hz}, 2 \mathrm{H}, 3,5-\mathrm{C}_{6} H_{4}\right), 7.81(\mathrm{~d}, \mathrm{~J}=8.2 \mathrm{~Hz}$, $2 \mathrm{H}, 2,6-\mathrm{C}_{6} \mathrm{H}_{4}$ ).

2-[3-Methyl-1-(2,4,6-trimethylbenzenesulfonyl)-aziridin-2-ylmethylene]-malonic acid diethyl ester (3d). 3-Methyl-1-(mesitylsulfonyl)-aziridine 3d was prepared in the same manner as 3a from $\mathbf{2 d}$ by condensation with diethyl malonate (95\% yield). oil; IR $\left(\mathrm{CCl}_{4}\right) 2990,1720,1600,1440,1370,1330,1160 \mathrm{~cm}^{-1}$; ${ }^{1} \mathrm{H}$ NMR $\delta 1.28+1.33\left(2 \mathrm{xt}, \mathrm{J}=7.1 \mathrm{~Hz}, 6 \mathrm{H}, 2 \mathrm{x} \mathrm{OCH}_{2} \mathrm{CH}_{3}\right), 1.57(\mathrm{~d}, \mathrm{~J}=5.8 \mathrm{~Hz}, 3 \mathrm{H}, \mathrm{CH} \mathrm{CHN}), 2.30$ (s, 3H, 4$\left.\mathrm{CH}_{3} \mathrm{Ph}\right), 2.67\left(\mathrm{~s}, 6 \mathrm{H}, 2,6-\left(\mathrm{CH}_{3}\right)_{2} \mathrm{Ph}\right), 2.95-3.16\left(\mathrm{~m}, 1 \mathrm{H}, \mathrm{CH}_{3} \mathrm{CHN}\right), 3.58(\mathrm{dd}, \mathrm{J}=3.9,9.7 \mathrm{~Hz}, 1 \mathrm{H}, \mathrm{NCHCH}=\mathrm{C})$, 
4.22-4.31 (2q, J = 7.1 Hz, 4H, 2x OCH $\left.\mathrm{CH}_{3}\right), 6.78(\mathrm{~d}, \mathrm{~J}=9.7 \mathrm{~Hz}, 1 \mathrm{H}, \mathrm{CH}=\mathrm{C}), 6.95(\mathrm{~s}, 2 \mathrm{H}, 3,5-\mathrm{Ph}) ; \mathrm{HRMS}$ $(\mathrm{M})^{+}$; Calcd for $\mathrm{C}_{20} \mathrm{H}_{27} \mathrm{NO}_{6} \mathrm{~S}: 409.1559$; Found: 409.1558 .

2-[3-Hexyl-1-(2,4,6-trimethylbenzenesulfonyl)-aziridin-2-ylmethylene]-malonic acid diethyl ester (3e). 3-Hexyl-1-(mesitylenesulfonyl)-aziridine 3e was prepared in the manner of 3d from ethyl 3-hexylaziridin-2-carboxylate via the $\mathrm{N}$-mesityl-aziridine ( $83 \%$ yield), reduction $(59 \%$ yield) and condensation with diethyl malonate ( $97 \%$ yield) as an oil; IR $\left(\mathrm{CCl}_{4}\right) 2930,1730,1600,1465,1380,1330,1245,1160 \mathrm{~cm}^{-1} ;{ }^{1} \mathrm{H}$ NMR $\left(\mathrm{CDCl}_{3}\right) \delta$ 0.85-0.97 (m, 3H, $\left.\mathrm{CH}_{3} \mathrm{CH}_{2} \mathrm{CH}_{2}\right), 1.15-1.50\left(\mathrm{~m}, 14 \mathrm{H}, 2 \mathrm{x} \mathrm{OCH}_{2} \mathrm{CH}_{3}, \mathrm{CH}_{3}\left(\mathrm{CH}_{2}\right)_{4} \mathrm{CH}_{2}\right), 1.60-$ $1.85\left(\mathrm{~m}, 2 \mathrm{H}, \mathrm{CH}_{2} \mathrm{CHN}\right), 2.30\left(\mathrm{~s}, 3 \mathrm{H}, 4-\mathrm{CH}_{3} \mathrm{C}_{6} \mathrm{H}_{2}\right), 2.68\left(\mathrm{~s}, 6 \mathrm{H}, 2,6-\left(\mathrm{CH}_{3}\right)_{2} \mathrm{C}_{6} \mathrm{H}_{2}\right), 2.95-3.12(\mathrm{~m}, 1 \mathrm{H}, \mathrm{HexCHN})$, $3.54(\mathrm{dd}, \mathrm{J}=3.8,10 \mathrm{~Hz}, 1 \mathrm{H}, \mathrm{NCHCH}=\mathrm{C}), 4.28\left(\mathrm{dq}, \mathrm{J}=6.4,7.1 \mathrm{~Hz}, 4 \mathrm{H}, 2 \mathrm{x} \mathrm{OCH} \mathrm{CH}_{3}\right), 6.95(\mathrm{~s}, 2 \mathrm{H}, 3,5-$ $\left.\mathrm{C}_{6} H_{2}\right), 7.01(\mathrm{~d}, \mathrm{~J}=10 \mathrm{~Hz}, 1 \mathrm{H}, \mathrm{CH}=\mathrm{C})$, ; HRMS $(\mathrm{M})^{+}$; Calcd for $\mathrm{C}_{25} \mathrm{H}_{37} \mathrm{NO}_{6} \mathrm{~S}: 479.2342$; Found: 479.2337 amu.

Reaction with Higher-Order Alkylcopper Reagents. A stirred, cooled $\left(-78^{\circ} \mathrm{C}\right)$ solution of 3 equiv of the copper reagents in ether or THF $(10 \mathrm{~mL})$, was treated with a solution of $3 \mathbf{a}$ or $\mathbf{3 b}(0.80 \mathrm{mmol})$ in ether (or THF; $5 \mathrm{~mL}$ ). The mixture was allowed to warm to $-30^{\circ} \mathrm{C}$, and stirring was continued at this temperature for $3 \mathrm{~h}$, when it was poured into a 3:1 mixture of saturated $\mathrm{NH}_{4} \mathrm{Cl}$ aqueous solution and $25 \%$ ammonia solution (100 $\mathrm{mL}$ ). The usual workup procedure followed by column chromatography (hexane-EtOAc), afforded the products.

The alkylcopper reagents were prepared as follows. $\mathrm{Me}_{2} \mathrm{Cu}(\mathrm{CN}) \mathrm{Li}_{2}$ : An ether solution of $\mathrm{MeLi}(1.6 \mathrm{M}$, $3.0 \mathrm{~mL}, 4.8 \mathrm{mmol})$ was added slowly to a precooled $\left(-78{ }^{\circ} \mathrm{C}\right)$ suspension of $\mathrm{CuCN}(0.22 \mathrm{~g}, 2.4 \mathrm{mmol})$ in ether (or THF; $10 \mathrm{~mL}$ ). The mixture was allowed to warm to $0{ }^{\circ} \mathrm{C}$, and then after $10 \mathrm{~min}$, was cooled to $-78^{\circ} \mathrm{C}$. $\mathrm{Bu}_{2} \mathrm{Cu}(\mathrm{CN}) \mathrm{Li}_{2}$ : A procedure similar to that above, except for the use of $\mathrm{BuLi}$ (a $1.6 \mathrm{M}$ hexane solution) instead of MeLi. The preparation was carried out at $-50{ }^{\circ} \mathrm{C}$ instead of $0{ }^{\circ} \mathrm{C} . \mathbf{B u}_{2} \mathbf{C u}(\mathbf{C N}) \mathbf{L i}_{2} \cdot \mathbf{B F}_{3}: \mathrm{BF}_{3} \mathrm{Et}_{2} \mathrm{O}(0.65 \mathrm{~mL}$, $2.4 \mathrm{mmol}$ ) was added to $\mathrm{Bu}_{2} \mathrm{Cu}(\mathrm{CN}) \mathrm{Li}_{2}$ (prepared as described above) at $-78{ }^{\circ} \mathrm{C}$, and the mixture was stirred for $5 \mathrm{~min}$.

Reaction with Butylmagnesiocuprate $\mathbf{B F}_{\mathbf{3}}$ Reagents. $\mathrm{BuMgBr}(1.6 \mathrm{M}, 1.3 \mathrm{~mL}, 2.0 \mathrm{mmol}$ ) in ether (or THF) was added by syringe to a stirred, cooled $\left(-78^{\circ} \mathrm{C}\right)$ slurry of $\mathrm{CuCN}(0.18 \mathrm{~g}, 2.0 \mathrm{mmol}$ ) in dry ether (or THF; $10 \mathrm{~mL})$, and the mixture was allowed to warm to $0{ }^{\circ} \mathrm{C} . \mathrm{BF}_{3} \mathrm{Et}_{2} \mathrm{O}(0.54 \mathrm{~mL}, 2.0 \mathrm{mmol})$ was added to the above mixture at $-78{ }^{\circ} \mathrm{C}$, which was then stirred for $5 \mathrm{~min}$. A solution of diethyl aziridinyl-methylenemalonate $3 \mathrm{a}(0.30 \mathrm{~g}, 0.67 \mathrm{mmol}$ ) in dry ether (or THF; $5 \mathrm{~mL}$ ) was then added dropwise to the above reagent and the reaction mixture was then allowed to $-10{ }^{\circ} \mathrm{C}$ (or $-30^{\circ} \mathrm{C}$ in the case of THF solution). Stirring was continued for $2 \mathrm{~h}$ (or $3 \mathrm{~h}$ in the case of THF solution) at the respective temperatures. The reaction mixture was poured into a 3:1 mixture of saturated $\mathrm{NH}_{4} \mathrm{Cl}$ aqueous solution and $25 \%$ ammonia solution $(100 \mathrm{~mL})$, processed as usual and subjected to column chromatography (hexane-EtOAc (7:1)) to give the products.

Reaction with Grignard Reagents Catalyzed by CuCN. A stirred, cooled $\left(-78{ }^{\circ} \mathrm{C}\right)$ mixture of diethyl aziridinyl-methylenemalonate $3(0.67 \mathrm{mmol})$ and $\mathrm{CuCN}(0.006 \mathrm{~g}, 0.067 \mathrm{mmol})$ in the required solvents $(15$ $\mathrm{mL}$ ) was treated with a Grignard reagent $(0.73 \mathrm{mmol})$, and after $15 \mathrm{~min}$, the mixture was allowed to warm to room temperature over $3 \mathrm{~h}$. Saturated aqueous $\mathrm{NH}_{4} \mathrm{Cl}$ solution $(50 \mathrm{~mL})$ was added, and the usual workup procedure followed by column chromatography (hexane-EtOAc) gave the products described. 
Reaction with Alkenylcupratemagnesium bromide dimethylsulfide reagent. A reported method ${ }^{12}$ was used as follows: The dimethyl sulfide complex of cuprous bromide $(0.14 \mathrm{~g}, 0.67 \mathrm{mmol})$ was placed in a $50-\mathrm{mL}$ flask maintained under argon. Dimethyl sulfide $(0.67 \mathrm{~mL})$ and ether $(0.84 \mathrm{~mL})$ were then added separately, and the resulting solution was cooled to $-45{ }^{\circ} \mathrm{C}$. The stirred mixture was treated with an etherial solution of butylmagnesium bromide $(1.0 \mathrm{M}, 0.74 \mathrm{~mL}, 0.74 \mathrm{mmol})$, and after $1.5 \mathrm{~h}$, with 1-hexyne $(0.084 \mathrm{~mL}$, $0.74 \mathrm{mmol}$ ). The mixture was allowed to warm to $-23{ }^{\circ} \mathrm{C}$, and was stirred at this temperature for $2.25 \mathrm{~h}$. The resulting dark green solution was cooled to $-50^{\circ} \mathrm{C}$, and treated with a solution in ether $(3 \mathrm{~mL})$ of diethyl aziridinyl-methylenemalonate $3 \mathrm{a}(0.30 \mathrm{~g}, 0.67 \mathrm{mmol})$. The mixture was allowed to warm to $-30{ }^{\circ} \mathrm{C}$, stirred at this temperature for $2 \mathrm{~h}$, and then at $0{ }^{\circ} \mathrm{C}$ for $2 \mathrm{~h}$. The mixture was treated with saturated aqueous $\mathrm{NH}_{4} \mathrm{Cl}$ solution and $25 \%$ aqueous ammonia $(3: 1,25 \mathrm{~mL})$, processed as usual, and column chromatography (hexaneEtOAc $(10: 1))$ of the crude material gave the product $(0.20 \mathrm{~g})$.

Reaction with Tributyltin Cuprate. The reported method was used as follows: ${ }^{13} \mathrm{n}-\mathrm{BuLi}$ (1.6M in hexane, $0.94 \mathrm{~mL}, 1.5 \mathrm{mmol})$ was added to a stirred, cooled $\left(-78^{\circ} \mathrm{C}\right)$ slurry of $\mathrm{CuCN}(0.067 \mathrm{~g}, 0.75 \mathrm{mmol})$ in ether $(10 \mathrm{~mL})$. The mixture was allowed to warm slowly to $-50{ }^{\circ} \mathrm{C}$, recooled to $-78{ }^{\circ} \mathrm{C}$, whereon $\mathrm{n}-\mathrm{Bu}_{3} \mathrm{SnH}$ $(0.40 \mathrm{~mL}, 1.5 \mathrm{mmol}$ ) was added by syringe. Stirring was continued for $15 \mathrm{~min}$, when diethyl aziridinylmethylenemalonate $3 \mathbf{a}(0.30 \mathrm{~g}, 0.67 \mathrm{mmol})$ dissolved in ether $(5 \mathrm{~mL})$ was added. This mixture was allowed to warm to $-30{ }^{\circ} \mathrm{C}$ over $\mathrm{lh}$, stirred at this temperature for $3 \mathrm{~h}$ and then treated with a $3: 1$ mixture of saturated aqueous $\mathrm{NH}_{4} \mathrm{Cl}$ and $25 \%$ aqueous ammonia $(25 \mathrm{~mL})$. The usual processing followed by column chromatography (hexane-EtOAc (10:1 to $7: 1))$ gave $4 \mathbf{e}(0.08 \mathrm{~g}, 16 \%)$ and $5 \mathbf{e}(0.15 \mathrm{~g}, 30 \%)$.

Reaction with Sodium Thiophenoxide. A solution of thiophenol $(0.073 \mathrm{~mL}, 0.74 \mathrm{mmol})$ in THF $(2 \mathrm{~mL})$ was added to a stirred, cooled $\left(0^{\circ} \mathrm{C}\right)$ suspension of sodium hydride $(0.018 \mathrm{~g}, 0.74 \mathrm{mmol})$ in THF $(10 \mathrm{~mL})$. The mixture was set aside for $30 \mathrm{~min}$, cooled to $-78{ }^{\circ} \mathrm{C}$ and treated with a solution of diethyl aziridinylmethylenemalonate $3 \mathrm{a}(0.30 \mathrm{~g}, 0.67 \mathrm{mmol})$ in THF $(5 \mathrm{~mL})$. After $10 \mathrm{~min}$, the mixture was allowed to warm to $50{ }^{\circ} \mathrm{C}$ when stirring was continued for $2.5 \mathrm{~h}$ prior to the addition of saturated aqueous $\mathrm{NH}_{4} \mathrm{Cl}$ solution $(25 \mathrm{~mL})$. The reaction mixture was extracted with ether $(3 \times 20 \mathrm{~mL})$, the combined organic extracts washed with brine, dried $\left(\mathrm{MgSO}_{4}\right)$, and concentrated in vacuo. Column chromatography (hexane-EtOAc (5:1)) of the residue, gave $4 \mathbf{f}(0.24 \mathrm{~g}, 64 \%)$.

Reaction with K-Selectride. A solution of diethyl aziridinyl-methylenemalonate 3a $(0.33 \mathrm{~g}, 0.73 \mathrm{mmol})$ in dry THF $(7 \mathrm{~mL})$ was added to a stirred, cooled $\left(-78^{\circ} \mathrm{C}\right)$ solution of $\mathrm{K}$-Selectride $(1.0 \mathrm{M}, 0.80 \mathrm{~mL}, 0.80$ mmol) in THF. The reaction mixture was stirred for $15 \mathrm{~min}$ at $-78{ }^{\circ} \mathrm{C}$, allowed to warm to $0{ }^{\circ} \mathrm{C}$ over $1.5 \mathrm{~h}$, and after a further $1 \mathrm{~h}$ at this temperature, was treated successively with a $10 \% \mathrm{NaOH}$ aqueous solution $(0.3 \mathrm{~mL})$ and $35 \% \mathrm{H}_{2} \mathrm{O}_{2}(3 \mathrm{~mL})$, and set aside to attain room temperature, whereon it was poured into water. The mixture was extracted with ether $(3 \times 10 \mathrm{~mL})$, and the combined organic extracts washed successively with saturated aqueous $\mathrm{NaHCO}_{3}$ solution, brine, dried $\left(\mathrm{MgSO}_{4}\right)$, filtered, and concentrated in vacuo. Column chromatography (hexane-EtOAc (3:1)) of the residue afforded cyclopropane $5 \mathbf{g}(0.26 \mathrm{~g}, 79 \%)$ as an oil.

Syntheses of 5 from 4 and 8 from 7. Synthesis of $5 b$ from $4 b$ is representative. A stirred solution of aziridine $4 \mathrm{~b}(0.19 \mathrm{~g}, 0.37 \mathrm{mmol})$ in EtOH $(6 \mathrm{~mL})$ maintained under argon, was treated with a few drops of a solution $(1.3 \mathrm{M})$ of sodium ethoxide, set aside overnight at room temperature and then concentrated in vacuo. Column chromatography (hexane-EtOAc (7:1)) of the residue yielded cyclopropane $\mathbf{5 b}(0.18 \mathrm{~g}, 95 \%)$ as an oil

The following were obtained in a similar manner: 
3-Methyl-2-[1-(toluene-4-sulfonylamino)-heptyl]-cyclopropane-1,1-dicarboxylic acid diethyl ester (5a). Oil; IR $\left(\mathrm{CCl}_{4}\right) 3260,2925,1790,1465,1300,1165 \mathrm{~cm}^{-1} ;{ }^{1} \mathrm{H}$ NMR $\left(\mathrm{CDCl}_{3}\right) \delta 0.81-0.86(\mathrm{~m}, 3 \mathrm{H}$, $\mathrm{CH}_{3} \mathrm{CH}_{2} \mathrm{CH}_{2}$ ), 1.00-1.44 (m, $\left.18 \mathrm{H}, \mathrm{CH}_{3}\left(\mathrm{CH}_{2}\right)_{4} \mathrm{CHH}, \mathrm{CHCH}_{3}, 2 \mathrm{xOCH}_{2} \mathrm{CH}_{3}\right), 1.45-1.84\left(\mathrm{~m}, 3 \mathrm{H}, \mathrm{CH}_{3} \mathrm{CHCH}\right.$, $\left.\mathrm{CH}_{3}\left(\mathrm{CH}_{2}\right)_{4} \mathrm{CH} H\right), 2.39+2.42\left(2 \mathrm{xs}, 3 \mathrm{H}, \mathrm{C}_{6} \mathrm{H}_{4} \mathrm{CH}_{3}\right), 2.95-3.12(\mathrm{~m}, 0.5 \mathrm{H}, \mathrm{CHN}), 3.57-3.65(\mathrm{~m}, 0.5 \mathrm{H}, \mathrm{CHN}), 4.08-$ $4.24\left(\mathrm{~m}, 4 \mathrm{H}, 2 \mathrm{xOCH} \mathrm{CH}_{3}\right), 4.90(\mathrm{~d}, \mathrm{~J}=8.0 \mathrm{~Hz}, 0.5 \mathrm{H}, \mathrm{NH}), 4.96(\mathrm{~d}, \mathrm{~J}=8.4 \mathrm{~Hz}, 0.5 \mathrm{H}, \mathrm{NH}), 7.24-7.32(\mathrm{~m}, 2 \mathrm{H}$, 3, 5- $\left.\mathrm{C}_{6} \mathrm{H}_{4}\right), 7.72+7.84\left(2 \mathrm{xd}, \mathrm{J}=8.0 \mathrm{~Hz}, 2 \mathrm{H}, 2,6-\mathrm{C}_{6} H_{4}\right) ;{ }^{13} \mathrm{C} \mathrm{NMR}\left(\mathrm{CDCl}_{3}\right) \delta 9.0,12.8,14.0,14.1,21.4,22.4$, $24.3,24.7,25.0,28.9,29.1,31.5,35.3,35.6,35.8,37.0,38.5,40.1,50.4,52.7,61.1,61.4,61.5,61.6,126.8$, $127.1,129.4,129.5,136.4,139.1,143.0,143.1,166.7,167.8,168.2,170.3$; HRMS $(\mathrm{M}+1)^{+}$; Calcd for $\mathrm{C}_{24} \mathrm{H}_{38} \mathrm{NO}_{6} \mathrm{~S}: 468.24199$; Found: $468.24207 \mathrm{amu}$.

2-\{1-[3-Hexyl-1-(toluene-4-sulfonyl)-aziridin-2-yl]-pentyl\}-malonic acid diethyl ester (4b). Oil; IR $\left(\mathrm{CCl}_{4}\right) 2920,1730,1460,1330,1160 \mathrm{~cm}^{-1} ;{ }^{1} \mathrm{H}$ NMR $\left(\mathrm{CDCl}_{3}\right) \delta 0.74-1.04\left(\mathrm{~m}, 6 \mathrm{H}, 2 \mathrm{xCH}_{3} \mathrm{CH}_{2} \mathrm{CH}_{2}\right), 1.04-1.7$ (m, $\left.21 \mathrm{H}, \mathrm{CH}_{3}\left(\mathrm{CH}_{2}\right)_{4}, \mathrm{BuCH}, 2 \mathrm{xOCH}_{2} \mathrm{CH}_{3}, \mathrm{CH}_{3}\left(\mathrm{CH}_{2}\right)_{3}\right), 1.7-2.1\left(\mathrm{~m}, 2 \mathrm{H}, \mathrm{CH}_{2} \mathrm{CH}_{2} \mathrm{CHN}\right.$ ), 2.43 (s, 3H, $\left.\mathrm{C}_{6} \mathrm{H}_{4} \mathrm{CH}_{3}\right), 2.5-2.75(\mathrm{~m}, 1 \mathrm{H}, \mathrm{HexC} H \mathrm{~N}), 2.95(\mathrm{dd}, \mathrm{J}=5,10 \mathrm{~Hz}, 1 \mathrm{H}, \mathrm{NCHCHBu}), 3.28(\mathrm{~d}, \mathrm{~J}=3.9 \mathrm{~Hz}, 1 \mathrm{H}$, $\left.\mathrm{CH}\left(\mathrm{CO}_{2} \mathrm{Et}\right)_{2}\right), 4.12\left(\mathrm{q}, \mathrm{J}=7.0 \mathrm{~Hz}, 2 \mathrm{H}, \mathrm{OCH}_{2} \mathrm{CH}_{3}\right), 4.20\left(\mathrm{q}, \mathrm{J}=7.1 \mathrm{~Hz}, 2 \mathrm{H}, \mathrm{OCH}_{2} \mathrm{CH}_{3}\right), 7.30(\mathrm{~d}, \mathrm{~J}=8.3 \mathrm{~Hz}, 2 \mathrm{H}$, 3, 5- $\left.\mathrm{C}_{6} \mathrm{H}_{4}\right), 7.85\left(\mathrm{~d}, \mathrm{~J}=8.3 \mathrm{~Hz}, 2 \mathrm{H}, 2,6-\mathrm{C}_{6} \mathrm{H}_{4}\right)$; HRMS (M) ${ }^{+}$; Calcd for $\mathrm{C}_{27} \mathrm{H}_{43} \mathrm{NO}_{6} \mathrm{~S}$ : 509.2811; Found: 509.2811 amu.

3-Butyl-2-[1-(toluene-4-sulfonylamino)-heptyl]-cyclopropane-1,1-dicarboxylic acid diethyl ester. The mixture of (5b) and (6b); oil; ' ${ }^{\mathrm{H}} \mathrm{NMR}\left(\mathrm{CDCl}_{3}\right) \delta 0.81-0.93\left(\mathrm{~m}, 6 \mathrm{H}, 2 \mathrm{xCH}_{3} \mathrm{CH}_{2} \mathrm{CH}_{2}\right), 1.0-1.40(\mathrm{~m}, 20 \mathrm{H}$, $\left.\mathrm{CH}_{3}\left(\mathrm{CH}_{2}\right)_{2} \mathrm{CH}_{2} \mathrm{CH}, \mathrm{CH}_{3}\left(\mathrm{CH}_{2}\right)_{5}, 2 \mathrm{xOCH}_{2} \mathrm{CH}_{3}\right), 1.44-1.80\left(\mathrm{~m}, 4 \mathrm{H}, \mathrm{CH}_{2} \mathrm{CH}_{2} \mathrm{CHCH}\right), 2.41\left(\mathrm{~s}, 3 \mathrm{H}, \mathrm{C}_{6} \mathrm{H}_{4} \mathrm{CH}_{3}\right)$, 2.50-2.58 (m, 0.55H, CHN), 3.21-3.27 (m, 0.5H, CHN), 2.95-3.06 (m, <0.10H, CHN), 3.65-3.74 (m, $0.30 \mathrm{H}$, $\mathrm{CHN}), 4.11-4.24\left(\mathrm{~m}, 3 \mathrm{H}, \mathrm{OCH}_{2} \mathrm{CH}_{3}, \mathrm{OCHHCH}_{3}\right), 4.29\left(\mathrm{q}, \mathrm{J}=7.2 \mathrm{~Hz}, 1 \mathrm{H}, \mathrm{OCH} \mathrm{CH}_{3}\right), 4.54-4.59(\mathrm{~m}, 0.35 \mathrm{H}$, $\mathrm{NH}), 5.00(\mathrm{~d}, \mathrm{~J}=8.0 \mathrm{~Hz}, 0.5 \mathrm{H}, \mathrm{NH}), 6.48(\mathrm{~d}, \mathrm{~J}=11 \mathrm{~Hz}, 0.5 \mathrm{H}, \mathrm{CH}=\mathrm{C}), 7.24-7.31\left(\mathrm{~m}, 2 \mathrm{H}, 3,5-\mathrm{C}_{6} H_{4}\right), 7.70-7.78$ $\left(\mathrm{m}, 2 \mathrm{H}, 2,6-\mathrm{C}_{6} \mathrm{H}_{4}\right)$.

The single isomer (5b); oil; IR $\left(\mathrm{CCl}_{4}\right) 3260,2920,1720,1455,1320,1230 \mathrm{~cm}^{-1} ;{ }^{1} \mathrm{H} \mathrm{NMR}\left(\mathrm{CDCl}_{3}\right) \delta$ 0.70-0.95 (m, 6H, $\left.2 \mathrm{xCH}_{3} \mathrm{CH}_{2} \mathrm{CH}_{2}\right), 0.95-1.40\left(\mathrm{~m}, 20 \mathrm{H}, \mathrm{CH}_{3}\left(\mathrm{CH}_{2}\right)_{4}, \mathrm{CH}_{3}\left(\mathrm{CH}_{2}\right)_{3}, 2 \mathrm{xOCH}_{2} \mathrm{CH}_{3}\right), 1.50-1.60(\mathrm{~m}$, $\left.2 \mathrm{H}, \mathrm{CH}_{2} \mathrm{CH}_{2} \mathrm{CHN}\right), 1.60-1.75(\mathrm{~m}, 2 \mathrm{H}, \mathrm{CHCHBu}), 2.41\left(\mathrm{~s}, 3 \mathrm{H}, \mathrm{C}_{6} \mathrm{H}_{4} \mathrm{CH}_{3}\right), 3.50-3.85(\mathrm{~m}, 1 \mathrm{H}, \mathrm{CHN}), 4.16+4.18$ $\left(2 \mathrm{xq}, \mathrm{J}=7.1 \mathrm{~Hz}, 4 \mathrm{H}, 2 \times \mathrm{XOCH}_{2} \mathrm{CH}_{3}\right), 4.56(\mathrm{~d}, \mathrm{~J}=7.9 \mathrm{~Hz}, 1 \mathrm{H}, \mathrm{NH}), 7.27\left(\mathrm{~d}, \mathrm{~J}=8.3 \mathrm{~Hz}, 2 \mathrm{H}, 3,5-\mathrm{C}_{6} H_{4}\right), 7.75(\mathrm{~d}$, $\left.\mathrm{J}=8.3 \mathrm{~Hz}, 2 \mathrm{H}, 2,6-\mathrm{C}_{6} \mathrm{H}_{4}\right) ;{ }^{13} \mathrm{C} \mathrm{NMR}\left(\mathrm{CDCl}_{3}\right) \delta 14.0,21.4,22.4,23.2,23.9,29.2,29.7,31.0,31.3,31.6,35.2$, $35.4,36.7, \quad 50.4,61.1,61.6,126.9,129.5,138.9,143.1,167.0,170.3 ;$ HRMS $(\mathrm{M})^{+}$; Calcd for $\mathrm{C}_{27} \mathrm{H}_{43} \mathrm{NO}_{6} \mathrm{~S}: 509.2811$; Found: 509.2811 amu.

2-\{1-[3-Hexyl-1-(toluene-4-sulfonyl)-aziridin-2-yl]-2-propenyl\}-malonic acid diethyl ester (4c). Oil; IR $\left(\mathrm{CCl}_{4}\right) 2920,1730,1455,1330,1160 \mathrm{~cm}^{-1} ;{ }^{1} \mathrm{H}$ NMR $\left(\mathrm{CDCl}_{3}\right) \delta 0.76-1.10\left(\mathrm{~m}, 3 \mathrm{H}, \mathrm{CH}_{3} \mathrm{CH}_{2} \mathrm{CH}_{2}\right), 1.10-2.20$ $\left(\mathrm{m}, 16 \mathrm{H}, \mathrm{CH}_{3}\left(\mathrm{CH}_{2}\right)_{5}, 2 \mathrm{xOCH}_{2} \mathrm{CH}_{3}\right), 2.44\left(\mathrm{~s}, 3 \mathrm{H}, \mathrm{C}_{6} \mathrm{H}_{4} \mathrm{CH}_{3}\right), 2.50-2.75\left(\mathrm{~m}, 2 \mathrm{H}, \mathrm{HexC} H \mathrm{~N}, \mathrm{CHCH}=\mathrm{CH}_{2}\right), 3.09$ $\left(\mathrm{dd}, \mathrm{J}=5,8 \mathrm{~Hz}, 1 \mathrm{H}, \mathrm{NCHCHCH}=\mathrm{CH}_{2}\right), 3.31+3.41\left(2 \mathrm{xd}, \mathrm{J}=6 \mathrm{~Hz}, 1 \mathrm{H}, \mathrm{CH}\left(\mathrm{CO}_{2} \mathrm{Et}\right)_{2}\right), 4.00-4.35(\mathrm{~m}, 4 \mathrm{H}$, $\left.2 \mathrm{xOCH} \mathrm{CH}_{3}\right), 4.92-5.26\left(\mathrm{~m}, 2 \mathrm{H}, \mathrm{CH}=\mathrm{CH}_{2}\right), 5.38-6.10\left(\mathrm{~m}, 1 \mathrm{H}, \mathrm{CH}=\mathrm{CH}_{2}\right), 7.31\left(\mathrm{~d}, \mathrm{~J}=9 \mathrm{~Hz}, 2 \mathrm{H}, 3,5-\mathrm{C}_{6} H_{4}\right)$, 7.80-7.95 (m, 2H, 2, 6- $\left.\mathrm{C}_{6} H_{4}\right)$; HRMS (M+1) ${ }^{+}$; Calcd for $\mathrm{C}_{25} \mathrm{H}_{38} \mathrm{NO}_{6} \mathrm{~S}: 480.24199$; Found: $480.24187 \mathrm{amu}$.

2-[1-(Toluene-4-sulfonylamino)-heptyl]-3-vinyl-cyclopropane-1,1-dicarboxylic acid diethyl ester (5c). Oil; IR $\left(\mathrm{CCl}_{4}\right) 3260,2920,1720,1460,1320,1160 \mathrm{~cm}^{-1} ;{ }^{1} \mathrm{H} \mathrm{NMR}\left(\mathrm{CDCl}_{3}\right) \delta 0.83-0.94(\mathrm{~m}, 3 \mathrm{H}$, $\mathrm{CH}_{3} \mathrm{CH}_{2} \mathrm{CH}_{2}$ ), 1.10-1.30 (m, 14H, $\mathrm{CH}_{3}\left(\mathrm{CH}_{2}\right)_{4} \mathrm{CH}_{2}, 2 \mathrm{x} \mathrm{OCH}_{2} \mathrm{CH}_{3}$ ), 1.50-1.60 (m, 2H, $\mathrm{CH}\left(\mathrm{CH}_{2}\right)_{4} \mathrm{CH}_{2}$ ), 1.88 (dd, 
$\mathrm{J}=9.7,9.7 \mathrm{~Hz}, 0.90 \mathrm{H}, \mathrm{H}-3), 2.42+2.44\left(2 \mathrm{~s}, 3 \mathrm{H}, \mathrm{C}_{6} \mathrm{H}_{4} \mathrm{CH}_{3}\right), 2.35(\mathrm{dd}, \mathrm{J}=9.7,9.7 \mathrm{~Hz}, 0.90 \mathrm{H}, \mathrm{H}-2), 2.60-2.78$ (m, 0.20H, H-2, H-3), 3.60-3.70 (m, 0.90H, CHNH), $4.18\left(\mathrm{q}, \mathrm{J}=7.1 \mathrm{~Hz}, 4 \mathrm{H}, 2 \mathrm{x} \mathrm{OCH}_{2} \mathrm{CH}_{3}\right), 3.02-3.12(\mathrm{~m}$, $0.10 \mathrm{H}, \mathrm{CHNH}), 4.71(\mathrm{~d}, \mathrm{~J}=6.9 \mathrm{~Hz}, 1 \mathrm{H}, \mathrm{NH}), 5.01\left(\mathrm{dd}, \mathrm{J}=1.7,17 \mathrm{~Hz}, 1 \mathrm{H}, \mathrm{CH}=\mathrm{CH}_{2}\right), 5.20(\mathrm{dd}, \mathrm{J}=1.7,17 \mathrm{~Hz}$, $\left.1 \mathrm{H}, \mathrm{CH}=\mathrm{CH}_{2}\right), 5.29-5.38\left(\mathrm{~m}, 1 \mathrm{H}, \mathrm{CH}=\mathrm{CH}_{2}\right), 7.27\left(\mathrm{~d}, \mathrm{~J}=8.2 \mathrm{~Hz}, 1.8 \mathrm{H}, 3,5-\mathrm{C}_{6} H_{4}\right), 7.33(\mathrm{~d}, \mathrm{~J}=8.2 \mathrm{~Hz}, 0.2 \mathrm{H}, 3$, $\left.5-\mathrm{C}_{6} H_{4}\right), 7.73\left(\mathrm{~d}, \mathrm{~J}=8.2 \mathrm{~Hz}, 1.8 \mathrm{H}, 2,6-\mathrm{C}_{6} H_{4}\right), 7.93\left(\mathrm{~d}, \mathrm{~J}=8.2 \mathrm{~Hz}, 0.2 \mathrm{H}, 2,6-\mathrm{C}_{6} H_{4}\right) ;{ }^{13} \mathrm{C} \mathrm{NMR}\left(\mathrm{CDCl}_{3}\right) \delta 14.0$, $21.4,22.5,24.1,29.1,31.6,33.8,35.1,35.6,50.7,61.4,61.9,119.9,127.1,129.4,129.5,138.5,143.1,166.1$, 169.2; HRMS (M+1) ${ }^{+}$; Calcd for $\mathrm{C}_{25} \mathrm{H}_{38} \mathrm{NO}_{6} \mathrm{~S}: 480.24199$; Found: $480.24211 \mathrm{amu}$.

2-(2-Butyl-hex-1-enyl)-3-[1-(toluene-4-sulfonylamino)-heptyl]-cyclopropane-1,1-dicarboxylic acid diethyl ester (5d). Oil; IR $\left(\mathrm{CCl}_{4}\right) 3260,2960,1720,1450,1320,1160 \mathrm{~cm}^{-1} ;{ }^{1} \mathrm{H}$ NMR $\left(\mathrm{CDCl}_{3}\right) \delta 0.82-0.92(\mathrm{~m}$, $\left.9 \mathrm{H}, 3 \mathrm{xCH}_{3} \mathrm{CH}_{2} \mathrm{CH}_{2}\right), 1.12-1.33\left(\mathrm{~m}, 22 \mathrm{H}, \mathrm{CH}_{3}\left(\mathrm{CH}_{2}\right)_{4}, 2 \mathrm{xCH}_{3}\left(\mathrm{CH}_{2}\right)_{2}, 2 \mathrm{xOCH}_{2} \mathrm{CH}_{3}\right), 1.50-1.75(\mathrm{~m}, 2 \mathrm{H}$, $\left.\mathrm{CH}_{2} \mathrm{CHN}\right), 1.78(\mathrm{dd}, \mathrm{J}=9.7,10 \mathrm{~Hz}, 1 \mathrm{H}, \mathrm{H}-2), 1.82-2.05\left(\mathrm{~m}, 4 \mathrm{H}, \mathrm{CH}=\mathrm{C}\left(\mathrm{CH}_{2}\right)_{2}\right), 2.41\left(\mathrm{~s}, 3 \mathrm{H}, \mathrm{C}_{6} \mathrm{H}_{4} \mathrm{CH}_{3}\right), 2.50$ (dd, J = 9.5, 9.7 Hz, $1 \mathrm{H}, \mathrm{H}-3), 3.75-3.84(\mathrm{~m}, 0.90 \mathrm{H}, \mathrm{CHNH}), 4.06-4.22\left(\mathrm{~m}, 4 \mathrm{H}, 2 \mathrm{x} \mathrm{OCH} \mathrm{CH}_{3}\right), 3.00-3.10(\mathrm{~m}$, $0.10 \mathrm{H}, \mathrm{C} H \mathrm{NH}), 4.49(\mathrm{~d}, \mathrm{~J}=6.8 \mathrm{~Hz}, 0.12 \mathrm{H}, \mathrm{NH}), 4.65(\mathrm{~d}, \mathrm{~J}=6.8 \mathrm{~Hz}, 0.88 \mathrm{H}, \mathrm{NH}), 4.84(\mathrm{~d}, \mathrm{~J}=9.5 \mathrm{~Hz}, 1 \mathrm{H}$, $\mathrm{CH}=\mathrm{C}), 7.24\left(\mathrm{~d}, \mathrm{~J}=8.4 \mathrm{~Hz}, 2 \mathrm{H}, 3,5-\mathrm{C}_{6} H_{4}\right), 7.73\left(\mathrm{~d}, \mathrm{~J}=8.4 \mathrm{~Hz}, 1.8 \mathrm{H}, 2,6-\mathrm{C}_{6} H_{4}\right), 7.93(\mathrm{~d}, \mathrm{~J}=8.4 \mathrm{~Hz}, 0.2 \mathrm{H}, 2$, 6- $\mathrm{C}_{6} H_{4}$ ); HRMS $(\mathrm{M}+1)^{+}$; Calcd for $\mathrm{C}_{33} \mathrm{H}_{53} \mathrm{NO}_{6} \mathrm{~S}: 592.3672$; Found: 592.3670 amu.

2-\{[3-Hexyl-1-(toluene-4-sulfonyl)-aziridin-2-yl]-(tri-butylstannyl)-methyl\}-malonic acid diethyl ester (4e). Oil; IR $\left(\mathrm{CCl}_{4}\right) 2920,1730,1460,1330,1180 \mathrm{~cm}^{-1} ;{ }^{1} \mathrm{H}$ NMR $\left(\mathrm{CDCl}_{3}\right) \delta 0.72-1.05(\mathrm{~m}, 12 \mathrm{H}$, $\left.4 \times \mathrm{xCH}_{3} \mathrm{CH}_{2} \mathrm{CH}_{2}\right), 1.05-2.10\left(\mathrm{~m}, 34 \mathrm{H}, \mathrm{CH}_{3}\left(\mathrm{CH}_{2}\right)_{5}, 3 \mathrm{xCH}_{3}\left(\mathrm{CH}_{2}\right)_{3}, 2 \mathrm{xOCH}_{2} \mathrm{CH}_{3}\right), 2.12-2.35$ (m, 1H, CHSn), 2.43 (s, $3 \mathrm{H}, \mathrm{C}_{6} \mathrm{H}_{4} \mathrm{CH}_{3}$ ), 2.51-2.74 (m, 1H, HexCHN), 2.94 (dd, J =6, $\left.9 \mathrm{~Hz}, 1 \mathrm{H}, \mathrm{NCHCHSn}\right), 3.29$ (d, J = 6 Hz, $1 \mathrm{H}$, $\left.\mathrm{CH}\left(\mathrm{CO}_{2} \mathrm{Et}\right)_{2}\right), 4.12+4.19\left(2 \mathrm{xq}, \mathrm{J}=7 \mathrm{~Hz}, 4 \mathrm{H}, 2 \mathrm{xOCH}_{2} \mathrm{CH}_{3}\right), 7.30\left(\mathrm{~d}, \mathrm{~J}=8 \mathrm{~Hz}, 2 \mathrm{H}, 3,5-\mathrm{C}_{6} \mathrm{H}_{4}\right), 7.85(\mathrm{~d}, \mathrm{~J}=8$ $\left.\mathrm{Hz}, 2 \mathrm{H}, 2,6-\mathrm{C}_{6} H_{4}\right)$.

2-tri-Butylstannyl-3-[1-(toluene-4-sulfonylamino)-heptyl]-cyclopropane-1,1-dicarboxylic acid diethyl ester (5e). Oil; IR $\left(\mathrm{CCl}_{4}\right) 3270,2920,1720,1455,1320,1210 \mathrm{~cm}^{-1} ;{ }^{1} \mathrm{H}$ NMR $\left(\mathrm{CDCl}_{3}\right) \delta 0.81-0.93(\mathrm{~m}$, $12 \mathrm{H}, 4 \times \mathrm{CH}_{3} \mathrm{CH}_{2} \mathrm{CH}_{2}$ ), 1.00-1.40 (m, 29H, 2xOCH $\left.\mathrm{CH}_{3}, \mathrm{CH}_{3}\left(\mathrm{CH}_{2}\right)_{4}, 3 \times \mathrm{Sn}\left(\mathrm{CH}_{2}\right)_{3} \mathrm{CH}_{3}\right), 1.40-1.65(\mathrm{~m}, 4 \mathrm{H}$, $3 \times \mathrm{XnCH}_{2} \mathrm{CH}_{2}$ ), 1.65-1.75 (m, $\left.2 \mathrm{H}, \mathrm{CH}_{2} \mathrm{CHN}, \mathrm{CHCHSn}\right), 1.80-1.90(\mathrm{~m}, 1 \mathrm{H}, \mathrm{CHSn}), 2.41+2.42(2 \mathrm{xs}, 3 \mathrm{H}$, $\mathrm{C}_{6} \mathrm{H}_{4} \mathrm{CH}_{3}$ ), 2.88-3.08 (m, 0.25H, CHN), 3.59-3.64 (m, 0.75H, CHN), 4.10-4.35 (m, 4H, 2xOCH $\left.2 \mathrm{CH}_{3}\right), 4.73$ (d, $\mathrm{J}=7.6 \mathrm{~Hz}, 1 \mathrm{H}, \mathrm{NH}), 7.25-7.29\left(\mathrm{~m}, 2 \mathrm{H}, 3,5-\mathrm{C}_{6} H_{4}\right), 7.74-7.79\left(\mathrm{~m}, 2 \mathrm{H}, 2,6-\mathrm{C}_{6} \mathrm{H}_{4}\right)$.

2-\{|3-Hexyl-1-(toluene-4-sulfonyl)-aziridin-2-yl]-phenylthio-methyl\}-malonic acid diethyl ester (4f). Oil; IR $\left(\mathrm{CCl}_{4}\right) 2920,1730,1440,1330,1160 \mathrm{~cm}^{-1} ;{ }^{1} \mathrm{H} \mathrm{NMR}\left(\mathrm{CDCl}_{3}\right) \delta 0.75-1.04\left(\mathrm{~m}, 3 \mathrm{H}, \mathrm{CH}_{3} \mathrm{CH}_{2} \mathrm{CH}_{2}\right), 1.04-$ $1.5\left(\mathrm{~m}, 14 \mathrm{H}, \mathrm{CH}_{3}\left(\mathrm{CH}_{2}\right)_{4}, 2 \mathrm{xOCH}_{2} \mathrm{CH}_{3}\right), 1.5-1.9\left(\mathrm{~m}, 2 \mathrm{H}, \mathrm{CH}_{2} \mathrm{CHN}\right), 2.34+2.43\left(2 \mathrm{xs}, 3 \mathrm{H}, \mathrm{C}_{6} \mathrm{H}_{4} \mathrm{CH}_{3}\right), 1.75-3.04$ $(\mathrm{m}, 1 \mathrm{H}, \mathrm{CHSPh}), 3.1-3.4(\mathrm{~m}, 1 \mathrm{H}, \mathrm{HexC} H \mathrm{~N}), 3.42-3.62\left(\mathrm{~m}, 2 \mathrm{H}, \mathrm{NCHCHS}, \mathrm{C} H\left(\mathrm{CO}_{2} \mathrm{Et}\right)_{2}\right), 4.05-4.32(\mathrm{~m}, 4 \mathrm{H}$, $2 \mathrm{xOCH}_{2} \mathrm{CH}_{3}$ ), 7.16-7.50 (m, 7H, SPh, 3, 5- $\left.\mathrm{C}_{6} \mathrm{H}_{4} \mathrm{CH}_{3}\right), 7.73-7.90\left(\mathrm{~m}, 2 \mathrm{H}, 2,6-\mathrm{C}_{6} \mathrm{H}_{4} \mathrm{CH}_{3}\right)$; HRMS (M) ; Calcd for $\mathrm{C}_{29} \mathrm{H}_{39} \mathrm{NO}_{6} \mathrm{~S}_{2}: 561.2219$; Found: $561.2220 \mathrm{amu}$.

2-[1-(Toluene-4-sulfonylamino)-heptyl]-cyclopropane-1,1-dicarboxylic acid diethyl ester (5g). $\mathrm{mp}$ : $69-71{ }^{\circ} \mathrm{C}$; IR $\left(\mathrm{CCl}_{4}\right) 3260,2920,1715,1440,1320 \mathrm{~cm}^{-1} ;{ }^{1} \mathrm{H}$ NMR $\left(\mathrm{CDCl}_{3}\right) \delta 0.84(\mathrm{t}, \mathrm{J}=7.2 \mathrm{~Hz}, 3 \mathrm{H}$, $\left.\mathrm{CH}_{3} \mathrm{CH}_{2} \mathrm{CH}_{2}\right), 1.04-1.32\left(\mathrm{~m}, 16 \mathrm{H}, \mathrm{CH}_{3}\left(\mathrm{CH}_{2}\right)_{5}, 2 \mathrm{xOCH}_{2} \mathrm{CH}_{3}\right), 1.32-1.45(\mathrm{~m}, 1 \mathrm{H}, \mathrm{NCHCHCH}), 1.45-1.55$ (m, $\left.1 \mathrm{H}, \mathrm{NCHCHCH})_{2}\right), 1.86\left(\mathrm{dt}, \mathrm{J}=8.5,8.5 \mathrm{~Hz}, 1 \mathrm{H}, \mathrm{NCHCHCH}_{2}\right), 2.42\left(\mathrm{~s}, 3 \mathrm{H}, \mathrm{C}_{6} \mathrm{H}_{4} \mathrm{CH}_{3}\right), 2.95-3.02(\mathrm{~m}, 1 \mathrm{H}$, $\mathrm{CHN}), 4.09-4.25\left(\mathrm{~m}, 4 \mathrm{H}, 2 \times \mathrm{xOCH}_{2} \mathrm{CH}_{3}\right), 4.66(\mathrm{~d}, \mathrm{~J}=8.4 \mathrm{~Hz}, 1 \mathrm{H}, \mathrm{NH}), 7.29\left(\mathrm{~d}, \mathrm{~J}=8.0 \mathrm{~Hz}, 2 \mathrm{H}, 3,5-\mathrm{C}_{6} H_{4}\right), 7.76$ $\left(\mathrm{d}, \mathrm{J}=8.0 \mathrm{~Hz}, 2 \mathrm{H}, 2,6-\mathrm{C}_{6} \mathrm{H}_{4}\right) ;{ }^{13} \mathrm{C}$ NMR $\left(\mathrm{CDCl}_{3}\right) \delta 14.0,19.9,21.5,22.4,24.9,28.9,29.7,31.6,32.7,34.3$, 
35.7, 53.7, 61.6, 127.1, 129.6, 138.4, 143.3, 167.7, 169.4; HRMS (M+1) ${ }^{+}$; Calcd for $\mathrm{C}_{23} \mathrm{H}_{36} \mathrm{NO}_{6} \mathrm{~S}: 454.22634$; Found: $454.22612 \mathrm{amu}$; Anal. Calcd for $\mathrm{C}_{23} \mathrm{H}_{35} \mathrm{NO}_{6} \mathrm{~S}: \mathrm{C}, 60.90 ; \mathrm{H}, 7.78 ; \mathrm{N}, 3.09 ; \mathrm{S}, 7.07$. Found: $\mathrm{C}, 60.78 ; \mathrm{H}$, $7.86 ; \mathrm{N}, 2.99 ; \mathrm{S}, 6.84$.

2-[1-(3-Hexyl-1-methylsulfonyl-aziridin-2-yl)-ethyl]-malonic acid diethyl acid (7a). Oil; IR ( $\left.\mathrm{CCl}_{4}\right)$ 2920, 1725, 1444, 1366, $1318 \mathrm{~cm}^{-1}$; 'H NMR $\delta 0.78-1.02\left(\mathrm{~m}, 3 \mathrm{H}, \mathrm{CH}_{3} \mathrm{CH}_{2} \mathrm{CH}_{2}\right), 1.09-1.6(\mathrm{~m}, 18 \mathrm{H}$, $\left.\mathrm{CH}_{3}\left(\mathrm{CH}_{2}\right)_{4} \mathrm{CHH}, \mathrm{CH}_{3} \mathrm{CH}, 2 \mathrm{xOCH}_{2} \mathrm{CH}_{3}\right), 1.6-1.9\left(\mathrm{~m}, 1 \mathrm{H}, \mathrm{CH}_{3}\left(\mathrm{CH}_{2}\right)_{4} \mathrm{CH}\right), 1.9-2.35\left(\mathrm{~m}, 1 \mathrm{H}, \mathrm{CH}_{3} \mathrm{CH}\right), 2.48-$ $2.65(\mathrm{~m}, 1 \mathrm{H}, \mathrm{HexC} H \mathrm{~N}), 2.78(\mathrm{dd}, \mathrm{J}=4.4,8.4 \mathrm{~Hz}, 1 \mathrm{H}, \mathrm{NCHCHCH}), 3.14\left(\mathrm{~s}, 3 \mathrm{H}, \mathrm{SO}_{2} \mathrm{CH}_{3}\right), 3.59(\mathrm{~d}, \mathrm{~J}=4.8$ $\left.\mathrm{Hz}, 1 \mathrm{H}, \mathrm{CH}\left(\mathrm{CO}_{2} \mathrm{Et}\right)_{2}\right), 4.22+4.25\left(2 \mathrm{xq}, \mathrm{J}=7.2 \mathrm{~Hz}, 4 \mathrm{H}, 2 \mathrm{xOCH} \mathrm{CH}_{3}\right)$; HRMS $(\mathrm{M}+1)^{+}$; Calcd for $\mathrm{C}_{18} \mathrm{H}_{34} \mathrm{NO}_{6} \mathrm{~S}$ : 392.21068; Found: 392.21063 amu.

2-[1-(Methylsulfonylamino)-heptyl]-3-methyl-cyclopropane-1,1-dicarboxylic acid diethyl ester (8a). The mixture with the aziridine-protonated compound (9a); oil; IR $\left(\mathrm{CCl}_{4}\right) 3260,2920,1730,1440,1340,1150$ $\mathrm{cm}^{-1} ;{ }^{1} \mathrm{H}$ NMR $\left(\mathrm{CDCl}_{3}\right) \delta$ 0.85-0.90 (m, 3H), 1.11-1.6 (m, 18H), 1.71-1.96 (m, 2H), $2.16(\mathrm{dd}, \mathrm{J}=7.2,7.2 \mathrm{~Hz}$, $0.5 \mathrm{H}), 2.5-2.6(\mathrm{~m}, 0.14 \mathrm{H}), 2.90+2.98(2 \mathrm{~s}, 0.5 \mathrm{H}), 2.98+3.02(2 \mathrm{~s}, 2.5 \mathrm{H}), 3.12-3.16(\mathrm{~m}, 0.5 \mathrm{H}), 3.40-3.49(\mathrm{~m}$, $0.07 \mathrm{H}), 3.50-3.51(\mathrm{~m}, 0.07 \mathrm{H}), 3.66-3.80(\mathrm{~m}, 0.5 \mathrm{H}), 4.14-4.31(\mathrm{~m}, 4 \mathrm{H}), 4.69(\mathrm{~d}, \mathrm{~J}=8.0 \mathrm{~Hz}, 0.3 \mathrm{H}), 4.80(\mathrm{~d}, \mathrm{~J}=$ $8.4 \mathrm{~Hz}, 0.5 \mathrm{H}), 5.02+5.08(2 \mathrm{xd}, \mathrm{J}=8 \mathrm{~Hz}, 0.07 \mathrm{H}), 6.9(\mathrm{~d}, \mathrm{~J}=8 \mathrm{~Hz}, 0.04 \mathrm{H}), 7.04(\mathrm{dd}, \mathrm{J}=8,8 \mathrm{~Hz}, 0.04 \mathrm{H})$.

The pure cyclopropane (8a); oil; IR $\left(\mathrm{CCl}_{4}\right) 3300,2920,1723,1455,1320,1150 \mathrm{~cm}^{-1} ;{ }^{1} \mathrm{H} \mathrm{NMR}\left(\mathrm{CDCl}_{3}\right) \delta$ 0.79-1.03 (m, 3H, $\left.\mathrm{CH}_{3} \mathrm{CH}_{2} \mathrm{CH}_{2}\right), 1.19-1.61\left(\mathrm{~m}, 19 \mathrm{H}, \mathrm{CH}_{3} \mathrm{CH}, \mathrm{CH}_{3}\left(\mathrm{CH}_{2}\right)_{5}, 2 \mathrm{xOCH}_{2} \mathrm{CH}_{3}\right), 1.61-1.93(\mathrm{~m}, 2 \mathrm{H}$, $\left.\mathrm{CH}_{3} \mathrm{CHCH}\right), 3.00\left(\mathrm{~s}, 3 \mathrm{H}, \mathrm{SO}_{2} \mathrm{CH}_{3}\right), 3.6-3.88(\mathrm{~m}, 1 \mathrm{H}, \mathrm{CHN}), 4.06-4.33\left(\mathrm{~m}, 4 \mathrm{H}, 2 \mathrm{xOCH} \mathrm{CH}_{3}\right), 4.47(\mathrm{~d}, \mathrm{~J}=8.0$ $\mathrm{Hz}, 1 \mathrm{H}, \mathrm{NH})$.

2-[1-(3-Hexyl-1-methylsulfonyl-aziridin-2-yl)-pentyl]-malonic acid diethyl ester (7b). Oil; IR ( $\left.\mathrm{CCl}_{4}\right)$ $2920,1735,1600,1465,1325,1150 \mathrm{~cm}^{-1}$; ${ }^{1} \mathrm{H}$ NMR $\left(\mathrm{CDCl}_{3}\right) \delta 0.80-1.08\left(\mathrm{~m}, 6 \mathrm{H}, 2 \mathrm{xCH}_{3} \mathrm{CH}_{2} \mathrm{CH}_{2}\right), 1.10-1.84$ (m, $\left.22 \mathrm{H}, \mathrm{CH}_{3}\left(\mathrm{CH}_{2}\right)_{4} \mathrm{CHH}, \mathrm{BuCH}, \mathrm{CH}_{3}\left(\mathrm{CH}_{2}\right)_{3}, 2 \mathrm{xOCH}_{2} \mathrm{CH}_{3}\right), 1.84-2.24(\mathrm{~m}, 1 \mathrm{H}, \mathrm{CH} H \mathrm{CHN}), 2.5-2.7(\mathrm{~m}, 1 \mathrm{H}$, CHN), $2.84(\mathrm{dd}, \mathrm{J}=4.0,8.2 \mathrm{~Hz}, 1 \mathrm{H}, \mathrm{NCHCHBu}), 3.14\left(\mathrm{~s}, 3 \mathrm{H}, \mathrm{SO}_{2} \mathrm{CH}_{3}\right), 3.64(\mathrm{~d}, \mathrm{~J}=4.1 \mathrm{~Hz}, 1 \mathrm{H}$, $\left.\mathrm{CH}\left(\mathrm{CO}_{2} \mathrm{Et}\right)_{2}\right), 4.22+4.24\left(2 \mathrm{xq}, \mathrm{J}=7.1 \mathrm{~Hz}, 4 \mathrm{H}, 2 \times \mathrm{OCH}_{2} \mathrm{CH}_{3}\right)$; HRMS $(\mathrm{M}+1)^{+}$; Calcd for $\mathrm{C}_{21} \mathrm{H}_{40} \mathrm{NO}_{6} \mathrm{~S}$ : 434.25764; Found: 434.25772 amu.

3-Butyl-2-[1-(methylsulfonylamino)-heptyl]-cyclopropane-1,1-dicarboxylic acid diethyl ester (8b). Oil; IR $\left(\mathrm{CCl}_{4}\right) 3270,2920,1720,1460,1325,1220 \mathrm{~cm}^{-1} ;{ }^{1} \mathrm{H}$ NMR $\left(\mathrm{CDCl}_{3}\right) \delta 0.75-0.93(\mathrm{~m}, 6 \mathrm{H}$, $\left.2 \times \mathrm{CH}_{3} \mathrm{CH}_{2} \mathrm{CH}_{2}\right), 1.21-1.64\left(\mathrm{~m}, 20 \mathrm{H}, \mathrm{CH}_{3}\left(\mathrm{CH}_{2}\right)_{4}, \mathrm{CH}_{3}\left(\mathrm{CH}_{2}\right)_{3}, 2 \mathrm{xOCH}_{2} \mathrm{CH}_{3}\right), 1.64-1.90\left(\mathrm{~m}, 4 \mathrm{H}, \mathrm{CH} \mathrm{CHN}_{2}\right.$, $\mathrm{C} H \mathrm{C} H \mathrm{Bu}), 2.99\left(\mathrm{~s}, 3 \mathrm{H}, \mathrm{SO}_{2} \mathrm{CH}_{3}\right), 3.6-3.95(\mathrm{~m}, 1 \mathrm{H}, \mathrm{CHN}), 4.18+4.20\left(2 \mathrm{xq}, \mathrm{J}=7.1 \mathrm{~Hz}, 4 \mathrm{H}, 2 \mathrm{xOCH}_{2} \mathrm{CH}_{3}\right), 4.53$ (d, J = 8.1 Hz, $1 \mathrm{H}, \mathrm{NH})$; HRMS $(\mathrm{M}+1)^{+}$; Calcd for $\mathrm{C}_{21} \mathrm{H}_{40} \mathrm{NO}_{6} \mathrm{~S}: 434.25764$; Found: $434.25772 \mathrm{amu}$.

3-Butyl-2-[1-(toluene-4-sulfonylamino)-ethyl]-cyclopropane-1,1-dicarboxylic acid diethyl ester (10). Oil; $\mathrm{Rf}=0.21$ (hexane:EtOAc $=3: 1$ ), column chromatography was conducted using hexane-EtOAc $(7: 1)$ as eluent; ${ }^{1} \mathrm{H}$ NMR $\left(\mathrm{CDCl}_{3}\right) \delta$ 0.83-0.91 (m, 3H, $\left.\mathrm{CH}_{3}\left(\mathrm{CH}_{2}\right)_{3}\right), 1.09-1.39\left(\mathrm{~m}, 14 \mathrm{H}, \mathrm{CH}_{3}\left(\mathrm{CH}_{2}\right)_{2} \mathrm{CHH}, \mathrm{CH} 3 \mathrm{CH}\right.$, $\left.2 \mathrm{xOCH}_{2} \mathrm{CH}_{3}\right), 1.57-1.80\left(\mathrm{~m}, 3 \mathrm{H}, \mathrm{CH}_{3}\left(\mathrm{CH}_{2}\right)_{2} \mathrm{CH} H \mathrm{CH}, \mathrm{BuCHCH}\right), 2.41\left(\mathrm{~s}, 3 \mathrm{H}, \mathrm{C}_{6} \mathrm{H}_{4} \mathrm{CH}_{3}\right), 3.00-3.08(\mathrm{~m}, 0.15 \mathrm{H}$, $\mathrm{CHNH}), 3.50-3.58(\mathrm{~m}, 0.85 \mathrm{H}, \mathrm{CHNH}), 4.09-4.23\left(\mathrm{~m}, 4 \mathrm{H}, 2 \mathrm{xOCH}_{2} \mathrm{CH}_{3}\right), 4.79(\mathrm{~d}, \mathrm{~J}=7.8 \mathrm{~Hz}, 0.85 \mathrm{H}, \mathrm{NH}), 4.92$ (d, J $=7.8 \mathrm{~Hz}, 0.15 \mathrm{H}, \mathrm{NH}), 7.29$ (d, J = 8.4 Hz, 2H, 3, 5- $\left.\mathrm{C}_{6} H_{4}\right), 7.76\left(\mathrm{~d}, \mathrm{~J}=8.4 \mathrm{~Hz}, 2 \mathrm{H}, 2,6-\mathrm{C}_{6} H_{4}\right)$. MS (CI): $\mathrm{m} / \mathrm{e}$ (relative intensity (\%)) $440(\mathrm{M}+1)^{+}(1.0), 394$ (19.8), 284 (28.7), 269 (41.3), 241 (20.4), 195 (14.6), 183 (10.7), 155 (19.9). 
3-Methyl-2-[1-(2,4,6-trimethylbenzenesulfonylamino)-ethyl]-cyclopropane-1,1-dicarboxylic acid diethyl ester (12). Purification by flash column chromatography using hexane-EtOAc (5:1) as eluent gave 12 $(0.13 \mathrm{~g}, 46 \%)$ as an oil; IR $\left(\mathrm{CCl}_{4}\right) 3300,2980,1720,1445,1370,1325,1210 \mathrm{~cm}^{-1} ;{ }^{1} \mathrm{H} \mathrm{NMR}\left(\mathrm{CDCl}_{3}\right) \delta 0.78(\mathrm{~d}$, $\left.\mathrm{J}=6.3 \mathrm{~Hz}, 1.8 \mathrm{H}, 3-\mathrm{CH}_{3}\right), 0.96\left(\mathrm{~d}, \mathrm{~J}=6.7 \mathrm{~Hz}, 1.2 \mathrm{H}, 3-\mathrm{CH}_{3}\right), 1.13\left(\mathrm{~d}, \mathrm{~J}=6.7 \mathrm{~Hz}, 1.8 \mathrm{H}, \mathrm{CH} \mathrm{CHNH}_{3}\right), 1.18-1.29$ (m, 7.2H, $\left.\mathrm{CH}_{3} \mathrm{CHNH}, 2 \mathrm{x} \mathrm{OCH} \mathrm{CH}_{3}\right), 1.39-1.46(\mathrm{~m}, 0.6 \mathrm{H}, \mathrm{H}-3), 1.61-1.68(\mathrm{~m}, 1 \mathrm{H}, \mathrm{H}-2, \mathrm{H}-3), 1.78-1.81$ (m, $0.4 \mathrm{H}, \mathrm{H}-2), 2.29+2.30\left(2 \mathrm{~s}, 3 \mathrm{H}, 4-\mathrm{CH}_{3} \mathrm{C}_{6} \mathrm{H}_{2}\right), 2.64+2.66+2.69\left(3 \mathrm{~s}, 6 \mathrm{H}, 2,6-(\mathrm{CH})_{2} \mathrm{C}_{6} \mathrm{H}_{2}\right), 2.98-3.04(\mathrm{~m}, 0.6 \mathrm{H}$, $\mathrm{C} H \mathrm{NH}), 3.48-3.52(\mathrm{~m}, 0.4 \mathrm{H}, \mathrm{CHNH}), 4.04-4.22\left(\mathrm{~m}, 4 \mathrm{H}, 2 \mathrm{x} \mathrm{OCH} \mathrm{CH}_{3}\right), 4.78(\mathrm{~d}, \mathrm{~J}=8.3 \mathrm{~Hz}, 0.4 \mathrm{H}, \mathrm{NH}), 4.97$ $(\mathrm{d}, \mathrm{J}=8.6 \mathrm{~Hz}, 0.6 \mathrm{H}, \mathrm{NH}), 6.94+6.97\left(2 \mathrm{~s}, 2 \mathrm{H}, 3,5-\mathrm{C}_{6} \mathrm{H}_{2}\right)$. HRMS $(\mathrm{M})^{+}$; Calcd for $\mathrm{C}_{21} \mathrm{H}_{31} \mathrm{NO}_{6} \mathrm{~S}: 425.1872$; Found: 425.1875 amu.

3-Butyl-2-[1-(2,4,6-trimethylbenzenesulfonylamino)-ethyl]-cyclopropane-1,1-dicarboxylic acid diethyl ester (13). Purification by flash column chromatography using hexane-EtOAc (7:1) as eluent gave 13 $(0.15 \mathrm{~g}, 48 \%)$ as an oil; IR $\left(\mathrm{CCl}_{4}\right) 3300,2960,1720,1450,1370,1320,1250,1215 \mathrm{~cm}^{-1} ;{ }^{1} \mathrm{H} \mathrm{NMR}\left(\mathrm{CDCl}_{3}\right) \delta$ $0.84\left(\mathrm{t}, \mathrm{J}=7.2 \mathrm{~Hz}, 3 \mathrm{H}, \mathrm{CH}_{3} \mathrm{CH}_{2} \mathrm{CH}_{2}\right), 1.09-1.35\left(\mathrm{~m}, 15 \mathrm{H}, 2 \mathrm{x} \mathrm{OCH}_{2} \mathrm{CH}_{3}, \mathrm{CH}_{3}\left(\mathrm{CH}_{2}\right)_{3} \mathrm{CH}, \mathrm{CH}_{3} \mathrm{CHNH}\right), 1.57-$ $1.62(\mathrm{~m}, 1 \mathrm{H}, \mathrm{H}-3), 1.68-1.73(\mathrm{~m}, 1 \mathrm{H}, \mathrm{H}-2), 2.28+2.30\left(2 \mathrm{~s}, 3 \mathrm{H}, 4-\mathrm{CH}_{3} \mathrm{C}_{6} \mathrm{H}_{2}\right), 2.64+2.65(2 \mathrm{~s}, 6 \mathrm{H}, 2,6-$ $\left.\left(\mathrm{CH}_{3}\right)_{2} \mathrm{C}_{6} \mathrm{H}_{2}\right), 2.98-3.01(\mathrm{~m}, 0.09 \mathrm{H}, \mathrm{CHNH}), 3.55-3.62(\mathrm{~m}, 0.91 \mathrm{H}, \mathrm{CHNH}), 4.10-4.23\left(\mathrm{~m}, 4 \mathrm{H}, 2 \mathrm{x} \mathrm{OCH} \mathrm{OH}_{3}\right)$, $4.52(\mathrm{~d}, \mathrm{~J}=8.3 \mathrm{~Hz}, 0.91 \mathrm{H}, \mathrm{NH}), 4.67(\mathrm{br} \mathrm{s}, 0.09 \mathrm{H}, \mathrm{NH}), 6.94+6.96\left(2 \mathrm{~s}, 2 \mathrm{H}, 3,5-\mathrm{C}_{6} H_{2}\right)$. HRMS $(\mathrm{M})^{+}$; Calcd for $\mathrm{C}_{24} \mathrm{H}_{37} \mathrm{NO}_{6} \mathrm{~S}: 467.2342$; Found: 467.2339 amu.

3-Methyl-2-[1-(2,4,6-trimethylbenzenesulfonylamino)-heptyl]-cyclopropane-1,1-dicarboxylic acid diethyl ester (14). Purification by flash column chromatography using hexane-EtOAc (7:1) as eluent gave 14 $(0.20 \mathrm{~g}, 60 \%)$ as an oil; IR $\left(\mathrm{CCl}_{4}\right) 3300,2920,1725,1455,1405,1370,1320,1210 \mathrm{~cm}^{-1} ;{ }^{1} \mathrm{H} \mathrm{NMR}\left(\mathrm{CDCl}_{3}\right) \delta$ $0.74\left(\mathrm{~d}, \mathrm{~J}=6.6 \mathrm{~Hz}, 0.63 \mathrm{H}, \mathrm{CH}_{3} \mathrm{CH}\right), 0.83\left(\mathrm{t}, \mathrm{J}=7.0 \mathrm{~Hz}, 3 \mathrm{H}, \mathrm{CH}_{3} \mathrm{CH}_{2} \mathrm{CH}_{2}\right), 0.98(\mathrm{~d}, \mathrm{~J}=6.6 \mathrm{~Hz}, 2.37 \mathrm{H}$, $\left.\mathrm{CH}_{3} \mathrm{CH}\right), 1.04-1.28\left(\mathrm{~m}, 14 \mathrm{H}, 2 \mathrm{x} \mathrm{OCH}_{2} \mathrm{CH}_{3}, \mathrm{CH}_{3}\left(\mathrm{CH}_{2}\right)_{4} \mathrm{CH}_{2}\right), 1.32-1.37\left(\mathrm{~m}, 0.42 \mathrm{H}, \mathrm{CH} \mathrm{CH}_{2} \mathrm{CH}\right), 1.53-1.83(\mathrm{~m}$, $\left.3.58 \mathrm{H}, \mathrm{CH}_{2} \mathrm{CH}, \mathrm{H}-2, \mathrm{H}-3\right), 2.28+2.29\left(2 \mathrm{~s}, 3 \mathrm{H}, 4-\mathrm{CH}_{3} \mathrm{C}_{6} \mathrm{H}_{2}\right), 2.64\left(\mathrm{~s}, 4.6 \mathrm{H}, 2,6-\left(\mathrm{CH}_{3}\right)_{2} \mathrm{C}_{6} \mathrm{H}_{2}\right), 2.67(\mathrm{~s}, 1.4 \mathrm{H}, 2$, 6- $\left.\left(\mathrm{CH}_{3}\right)_{2} \mathrm{C}_{6} \mathrm{H}_{2}\right), 2.98-3.04(\mathrm{~m}, 0.21 \mathrm{H}, \mathrm{C} H \mathrm{NH}), 3.61-3.68(\mathrm{~m}, 0.79 \mathrm{H}, \mathrm{C} H \mathrm{NH}), 4.09-4.24\left(\mathrm{~m}, 4 \mathrm{H}, 2 \mathrm{x} \mathrm{OCH} \mathrm{CH}_{3}\right)$, $4.49(\mathrm{~d}, \mathrm{~J}=8.0 \mathrm{~Hz}, 0.79 \mathrm{H}, \mathrm{NH}), 4.57(\mathrm{~d}, \mathrm{~J}=9.0 \mathrm{~Hz}, 0.21 \mathrm{H}, \mathrm{NH}), 6.93\left(\mathrm{~s}, 1.58 \mathrm{H}, 3,5-\mathrm{C}_{6} H_{2}\right), 6.97(\mathrm{~s}, 0.42 \mathrm{H}, 3$, 5- $\left.\mathrm{C}_{6} \mathrm{H}_{2}\right)$; HRMS $(\mathrm{M})^{+}$; Calcd for $\mathrm{C}_{26} \mathrm{H}_{41} \mathrm{NO}_{6} \mathrm{~S}$ : 495.2655; Found: $495.2654 \mathrm{amu}$.

3-Butyl-2-[1-(2,4,6-trimethylbenzenesulfonylamino)-heptyl]-cyclopropane-1,1-dicarboxylic acid diethyl ester (15). Purification by flash column chromatography using hexane-EtOAc (10:1) as eluent gave 15 $(0.25 \mathrm{~g}, 69 \%)$ as an oil; IR $\left(\mathrm{CCl}_{4}\right) 3310,2920,1720,1450,1370,1330,1220,1160 \mathrm{~cm}^{-1} ;{ }^{1} \mathrm{H} \mathrm{NMR}\left(\mathrm{CDCl}_{3}\right) \delta$ 0.81-0.86 (m, 6H, 2x CH3 $\left.\mathrm{CH}_{2} \mathrm{CH}_{2}\right), 1.06-1.30\left(\mathrm{~m}, 20 \mathrm{H}, \mathrm{CH}_{3}\left(\mathrm{CH}_{2}\right)_{4} \mathrm{CH}_{2}, \mathrm{CH}_{3}\left(\mathrm{CH}_{2}\right)_{3} \mathrm{CHCH}, 2 \mathrm{x} \mathrm{OCH}_{2} \mathrm{CH}_{3}\right)$, 1.48-1.52 (m, $\left.2 \mathrm{H}, \mathrm{CH}_{3}\left(\mathrm{CH}_{2}\right)_{4} \mathrm{CH}_{2}\right), 1.65-1.72(\mathrm{~m}, 2 \mathrm{H}, \mathrm{H}-2, \mathrm{H}-3), 2.28+2.29\left(2 \mathrm{~s}, 3 \mathrm{H}, 4-\mathrm{CH}_{3} \mathrm{C}_{6} \mathrm{H}_{2}\right), 2.64+2.66$ $\left(2 \mathrm{~s}, 6 \mathrm{H}, 2.6-\left(\mathrm{CH}_{3}\right)_{2} \mathrm{C}_{6} \mathrm{H}_{2}\right), 2.96(\mathrm{~m}, 0.10 \mathrm{H}, \mathrm{CHN}), 3.70-3.75(\mathrm{~m}, 0.90 \mathrm{H}, \mathrm{CHN}), 4.12-4.21(\mathrm{~m}, 4 \mathrm{H}, 2 \mathrm{x}$ $\left.\mathrm{OCH}_{2} \mathrm{CH}_{3}\right), 4.49(\mathrm{~d}, \mathrm{~J}=8.0 \mathrm{~Hz}, 0.90 \mathrm{H}, \mathrm{NH}), 4.58(\mathrm{~d}, \mathrm{~J}=8.0 \mathrm{~Hz}, 0.10 \mathrm{H}, \mathrm{NH}), 6.93+6.94\left(2 \mathrm{~s}, 2 \mathrm{H}, 3,5-\mathrm{C}_{6} \mathrm{H}_{2}\right)$; ${ }^{13} \mathrm{C} \mathrm{NMR}\left(\mathrm{CDCl}_{3}\right) \delta 14.0,20.8,22.4,23.0,23.1,24.0,29.2,31.0,31.3,31.6,35.3,35.5,36.7,50.3,61.1,61.6$, $131.9,136.2,138.4,141.8,167.0,170.7$; HRMS (M) ${ }^{+}$; Calcd for $\mathrm{C}_{29} \mathrm{H}_{47} \mathrm{NO}_{6} \mathrm{~S}: 537.3124$; Found: 537.3125 amu.

Methyl (2S, 3S)-3-methyl-1-(toluene-4-sulfonyl)-aziridin-2-carboxylate. Methyl (2S, 3S)-3-methyl-1trityl-aziridin-2-carboxylate $(3.2 \mathrm{~g}, 8.9 \mathrm{mmol})$ which was prepared according to a literature method ${ }^{24}$ was dissolved in $14 \mathrm{~mL}$ of chloroform and methanol $(1: 1 \mathrm{v} / \mathrm{v})$. To this solution was added $7 \mathrm{~mL}$ of trifluoroacetic acid under ice cooling. The mixture was stirred for $3 \mathrm{~h}$ in an ice bath and then concentrated in vacuo. 
Evaporation with newly added ether was repeated several times to remove trifluoroacetic acid as completely as possible. The residue was dissolved in ether again and 3-methyl-aziridine-2-carboxylate trifluoroacetate was extracted with water $(3 \times 30 \mathrm{~mL})$. To the aqueous extract was added sodium hydrogencarbonate $(3.5 \mathrm{~g}, 0.042$ $\mathrm{mol}$ ) and $30 \mathrm{~mL}$ of ethyl acetate. Tosyl chloride $(1.7 \mathrm{~g}, 8.9 \mathrm{mmol})$ was added to the mixture under vigorous stirring in an ice bath. After stirring overnight at room temperature, the ethyl acetate layer was separated from the aqueous layer which was extracted with another portion of ethyl acetate again. The combined organic layers were washed with brine, dried over $\mathrm{MgSO}_{4}$, and concentrated. The crude product thus obtained was purified by column chromatography (silica, hexane-EtOAc (3:1)) to give $1.2 \mathrm{~g}(50 \%)$ of methyl 1-tosylaziridinecarboxylate: oil; IR $\left(\mathrm{CCl}_{4}\right) 2960,1750,1440,1410,1340,1280,1200,1160 \mathrm{~cm}^{-1} ;{ }^{1} \mathrm{H} \mathrm{NMR}\left(\mathrm{CDCl}_{3}\right) \delta$ $1.32\left(\mathrm{~d}, \mathrm{~J}=5.6 \mathrm{~Hz}, 3 \mathrm{H}, \mathrm{CH}_{3} \mathrm{CHN}\right), 2.45\left(\mathrm{~s}, 3 \mathrm{H}, \mathrm{C}_{6} \mathrm{H}_{4} \mathrm{CH}_{3}\right), 3.10\left(\mathrm{dq}, \mathrm{J}=5.6,7.4 \mathrm{~Hz}, 1 \mathrm{H}, \mathrm{CH}_{3} \mathrm{CHN}\right), 3.39(\mathrm{~d}, \mathrm{~J}$ $=7.4 \mathrm{~Hz}, 1 \mathrm{H}, \mathrm{CHCO}), 3.74\left(\mathrm{~s}, 3 \mathrm{H}, \mathrm{OCH}_{3}\right), 7.34\left(\mathrm{~d}, \mathrm{~J}=8.1 \mathrm{~Hz}, 2 \mathrm{H}, 3,5-\mathrm{C}_{6} H_{4}\right), 7.85(\mathrm{~d}, \mathrm{~J}=8.4 \mathrm{~Hz}, 2 \mathrm{H}, 2,6-$ $\left.\mathrm{C}_{6} \mathrm{H}_{4}\right) ;{ }^{13} \mathrm{C} \mathrm{NMR}\left(\mathrm{CDCl}_{3}\right) \delta 12.2,21.7,40.1,41.2,52.6,128.0,129.8,134.4,145.0,166.3$.

(2S, 3S)-2-Formyl-3-methyl-1-(toluene-4-sulfonyl)-aziridine. A hexane solution of diisobutylaluminum-hydride $(1.0 \mathrm{M}, 5.4 \mathrm{~mL}, 5.4 \mathrm{mmol})$ was added to a dichloromethane solution $(22 \mathrm{~mL})$ of methyl cis-3-methyl-1-(toluene-4-sulfonyl)-aziridine-2-carboxylate $\left(1.2 \mathrm{~g}, 4.5 \mathrm{mmol}\right.$ ) at $-78{ }^{\circ} \mathrm{C}$ under Ar. After completion of the addition, the mixture was stirred for one hour and sodium fluoride $(1.9 \mathrm{~g})$ and water $(1.3 \mathrm{~mL})$ were added. The reaction mixture was then warmed slowly to room temperature and the white solid thus formed was collected. The filtrate was concentrated in vacuo and column chromatography (hexane-EtOAc (2:1)) of the residual oil afforded cis-2-formyl-3-methyl-1-(toluene-4-sulfonyl)-aziridine $(0.88 \mathrm{~g}, 3.7 \mathrm{mmol})$ in $82 \%$ yield also as an oil. IR $\left(\mathrm{CCl}_{4}\right) 2920,1730,1440,1400,1340,1215,1160 \mathrm{~cm}^{-1} ;{ }^{1} \mathrm{H}$ NMR $\left(\mathrm{CDCl}_{3}\right) \delta 1.39$ $\left(\mathrm{d}, \mathrm{J}=5.6 \mathrm{~Hz}, 3 \mathrm{H}, \mathrm{CH} \mathrm{CHN}_{3}\right), 2.46\left(\mathrm{~s}, 3 \mathrm{H}, \mathrm{CH}_{3} \mathrm{C}_{6} \mathrm{H}_{4}\right), 3.12-3.27(\mathrm{~m}, 2 \mathrm{H}, \mathrm{H}-2, \mathrm{H}-3), 7.36(\mathrm{~d}, \mathrm{~J}=8.0 \mathrm{~Hz}, 2 \mathrm{H}, 3$, $\left.5-\mathrm{C}_{6} H_{4}\right), 7.84\left(\mathrm{~d}, \mathrm{~J}=8.0 \mathrm{~Hz}, 2 \mathrm{H}, 2,6-\mathrm{C}_{6} H_{4}\right), 9.31(\mathrm{~d}, \mathrm{~J}=5.4 \mathrm{~Hz}, 1 \mathrm{H}, \mathrm{CHO}) ;{ }^{13} \mathrm{C} \mathrm{NMR}\left(\mathrm{CDCl}_{3}\right) \delta 12.9,21.5$, $40.6,46.4,127.8,129.8,145.1,195.3$.

$(2 R, 3 S)$-2-[3-Methyl-1-(toluene-4-sulfonyl)-aziridin-2-ylmethylene]-malonic acid diethyl ester (16). Diethyl cis-3-methyl-aziridinylmethylene-malonate was prepared from cis-2-formyl-3-methyl-1-tosyl-aziridine according to the standard method. After column chromatography (silica-gel, hexane-EtOAc (5:1)), the aziridine $16(1.2 \mathrm{~g}, 85 \%)$ was obtained as an oil. IR $\left(\mathrm{CCl}_{4}\right) 2980,1730,1440,1395,1335,1240,1160 \mathrm{~cm}^{-1}$; ${ }^{1} \mathrm{H}$ NMR $\left(\mathrm{CDCl}_{3}\right) \delta 1.21-1.43\left(\mathrm{~m}, 9 \mathrm{H}, \mathrm{CH}_{3} \mathrm{CHN}, 2 \mathrm{x} \mathrm{OCH}_{2} \mathrm{CH}_{3}\right), 2.45\left(\mathrm{~s}, 3 \mathrm{H}, \mathrm{CH}_{3} \mathrm{C}_{6} \mathrm{H}_{4}\right), 3.15(\mathrm{dq}, \mathrm{J}=5.9,7.4 \mathrm{~Hz}, 1 \mathrm{H}$, $\left.\mathrm{CH}_{3} \mathrm{CHN}\right), 3.70(\mathrm{dd}, \mathrm{J}=7.4,8.4 \mathrm{~Hz}, 1 \mathrm{H}, \mathrm{NCHCH}=\mathrm{C}), 4.23\left(\mathrm{q}, \mathrm{J}=7.1 \mathrm{~Hz}, 2 \mathrm{H}, \mathrm{OCH}_{2} \mathrm{CH}_{3}\right), 4.34(\mathrm{q}, \mathrm{J}=7.1 \mathrm{~Hz}$, $\left.2 \mathrm{H}, \mathrm{OCH}_{2} \mathrm{CH}_{3}\right), 6.61(\mathrm{~d}, \mathrm{~J}=8.4 \mathrm{~Hz}, 1 \mathrm{H}, \mathrm{CHC}=\mathrm{C}), 7.34\left(\mathrm{~d}, \mathrm{~J}=8.1 \mathrm{~Hz}, 2 \mathrm{H}, 3,5-\mathrm{C}_{6} H_{4}\right), 7.81(\mathrm{~d}, \mathrm{~J}=8.2 \mathrm{~Hz}, 2 \mathrm{H}$, 2, 6- $\left.\mathrm{C}_{6} \mathrm{H}_{4}\right) ;{ }^{13} \mathrm{C} \mathrm{NMR}\left(\mathrm{CDCl}_{3}\right) \delta 13.0,13.9,14.0,21.5,41.4,41.7,61.6,61.7,127.7,129.7,132.6,134.7$, 140.6, 144.7, 162.7, 163.7 .

3-Butyl-2-[1-(1S)-(toluene-4-sulfonylamino)-ethyl]-cyclopropane-1,1-dicarboxylic acid diethyl ester (18). Oil; Column chromatography, with hexane-EtOAc (7:1) as eluent; IR $\left(\mathrm{CCl}_{4}\right)$ 3300, 2920, 1720, 1550, $1370,1300,1250,1210 \mathrm{~cm}^{-1}$; ' $\mathrm{H} \mathrm{NMR}\left(\mathrm{CDCl}_{3}\right) \delta 0.85\left(\mathrm{t}, \mathrm{J}=6.4 \mathrm{~Hz}, 3 \mathrm{H}, \mathrm{CH}_{2} \mathrm{CH}_{2} \mathrm{CH}_{3}\right), 1.08(\mathrm{~d}, \mathrm{~J}=6.4 \mathrm{~Hz}$, $\left.3 \mathrm{H}, \mathrm{CH}_{3} \mathrm{CHN}\right), 1.10-1.41\left(\mathrm{~m}, 12 \mathrm{H},\left(\mathrm{CH}_{2}\right)_{3} \mathrm{CH}_{3}, 2 \mathrm{x} \mathrm{OCH}_{2} \mathrm{CH}_{3}\right), 1.76-1.81(\mathrm{~m}, 2 \mathrm{H}, \mathrm{H}-2, \mathrm{H}-3), 2.41(\mathrm{~s}, 3 \mathrm{H}$, $\left.\mathrm{C}_{6} \mathrm{H}_{4} \mathrm{CH}_{3}\right), 3.13-3.18(\mathrm{~m}, 1 \mathrm{H}, \mathrm{CHN}), 4.07-4.27\left(\mathrm{~m}, 4 \mathrm{H}, 2 \mathrm{x} \mathrm{OCH} \mathrm{CH}_{3}\right), 4.83(\mathrm{~d}, \mathrm{~J}=6.8 \mathrm{~Hz}, 1 \mathrm{H}, \mathrm{NH}), 7.27(\mathrm{~d}, \mathrm{~J}$ $\left.\left.=8.4 \mathrm{~Hz}, 2 \mathrm{H}, 3,5-\mathrm{C}_{6} H_{4}\right), 7.72\left(\mathrm{~d}, \mathrm{~J}=8.4 \mathrm{~Hz}, 2 \mathrm{H}, 2,6-\mathrm{C}_{6} H_{4}\right)\right) ;{ }^{13} \mathrm{C} \mathrm{NMR}\left(\mathrm{CDCl}_{3}\right) \delta 13.9,14.0,14.2,21.1,21.5$, $22.3,27.4,30.7,31.5,38.6,40.1,48.9,61.5,62.0,127.0,129.6,138.7,143.1,168.0,168.2$. 
6-Butyl-4-methyl-2-oxo-3-(toluene-4-sulfonyl)-3-aza-bicyclo[3.1.0]hexane-1-carboxylic acid ethyl ester (19). A stirred solution of $17(0.10 \mathrm{~g}, 0.23 \mathrm{mmol})$ in $\mathrm{EtOH}(7 \mathrm{~mL})$, maintained under argon, was treated with a few drops of $1.3 \mathrm{M}$ ethanolic solution of $\mathrm{NaOEt}$, set aside overnight at room temperature, and concentrated in vacuo. Flash column chromatography (hexane-EtOAc $(7: 1))$ of the residue gave $19(0.06 \mathrm{~g}$, $66 \%)$ as an oil; IR $\left(\mathrm{CCl}_{4}\right) 2960,1740,1720,1370,1330,1255,1170 \mathrm{~cm}^{-1} ;{ }^{1} \mathrm{H} \mathrm{NMR}\left(\mathrm{CDCl}_{3}\right) \delta 0.79(\mathrm{t}, \mathrm{J}=7.3$ $\left.\mathrm{Hz}, 3 \mathrm{H}, \mathrm{CH}_{2} \mathrm{CH}_{2} \mathrm{CH}_{3}\right), 1.01-1.30\left(\mathrm{~m}, 9 \mathrm{H},\left(\mathrm{CH}_{2}\right)_{3} \mathrm{CH}_{3}, \mathrm{OCH}_{2} \mathrm{CH}_{3}\right), 1.63$ (d, J = 6.4 Hz, 3H, CH $\mathrm{CHN}$ ), 2.02$2.07(\mathrm{~m}, 1 \mathrm{H}, \mathrm{CHBu}), 2.14(\mathrm{~d}, \mathrm{~J}=8.4 \mathrm{~Hz}, 1 \mathrm{H}, \mathrm{H}-5), 2.42\left(\mathrm{~s}, 3 \mathrm{H}, \mathrm{C}_{6} \mathrm{H}_{4} \mathrm{CH}_{3}\right), 4.16-4.23\left(\mathrm{~m}, 3 \mathrm{H}, \mathrm{OCH}_{2} \mathrm{CH}_{3}\right.$, $\left.\mathrm{CH}_{3} \mathrm{CHN}\right), 7.31\left(\mathrm{~d}, \mathrm{~J}=8.4 \mathrm{~Hz}, 2 \mathrm{H}, 3,5-\mathrm{C}_{6} H_{4}\right), 7.95\left(\mathrm{~d}, \mathrm{~J}=8.4 \mathrm{~Hz}, 2 \mathrm{H}, 2,6-\mathrm{C}_{6} H_{4}\right) ;{ }^{13} \mathrm{C} \mathrm{NMR}\left(\mathrm{CDCl}_{3}\right) \delta 13.8$. $14.1,21.6,21.8,22.1,23.0,30.8,33.3,34.2,52.3,61.8,128.7,129.4,135.6,145.2,165.9,167.9$.

Reactions with Hetero-Organocuprates, Standard procedure: An etherial or dimethyl sulfide (DMS) solution $(5 \mathrm{~mL})$ of a lithium alkoxide or lithium amide (obtained by treatment of the corresponding alcohol or amine $(0.74 \mathrm{mmol})$ with $\mathrm{MeLi}(0.46 \mathrm{~mL} ; 0.74 \mathrm{mmol})$ at $\left.0{ }^{\circ} \mathrm{C}\right)$ was added to a stirred, cooled $\left(-50{ }^{\circ} \mathrm{C}\right)$ suspension (or solution) of CuI $(0.14 \mathrm{~g}, 0.74 \mathrm{mmol})$ in ether or DMS $(5 \mathrm{~mL})$. The mixture was allowed to warm to $-30{ }^{\circ} \mathrm{C}$ and maintained at this temperature for $30 \mathrm{~min}$, whereon it was cooled to $-78^{\circ} \mathrm{C}$ and treated with the appropriate Grignard reagent $(1.0 \mathrm{M}$ in ether, $1.4 \mathrm{mmol})$ followed immediately by addition of a solution of the aziridine 3a $\left(0.30 \mathrm{~g}, 0.67 \mathrm{mmol}\right.$ ) in ether (or DMS; $5 \mathrm{~mL}$ ). After a further period of $15 \mathrm{~min}$ at $-78{ }^{\circ} \mathrm{C}$, the mixture was allowed to attain room temperature over $3 \mathrm{~h}$. With alkoxide hetero-cuprates, the reaction mixture was treated with saturated aqueous $\mathrm{NH}_{4} \mathrm{Cl}$ solution $(50 \mathrm{~mL})$, whereas with amide hetero-cuprates, the reaction was quenched by addition of $5 \%$ aqueous $\mathrm{H}_{2} \mathrm{SO}_{4}(50 \mathrm{~mL}$ ). The resultant mixtures were treated with ether ( 50 $\mathrm{mL}$ ), filtered through "hyflo", the inorganic material washed with ether, and the combined ether layers washed ( $3 \times 100 \mathrm{~mL}$ ) with a saturated aqueous $\mathrm{NH}_{4} \mathrm{Cl}$ solution - $25 \%$ aqueous ammonia mixture (3:1), brine, dried $\left(\mathrm{MgSO}_{4}\right)$ and concentrated in vacuo. Flash column chromatography (hexane-EtOAc (7:1)) of the residue gave cyclopropane 5a.

\section{REFERENCES AND NOTES}

\# Funaki, I.; Thijs, L.; Zwanenburg. B. Tetrahedron 1996, submitted for publication.

1. Kasatkin, A. N.; Kulak, A. N.; Biktimirov, R. Kh.; Tolstikov, G. A. Tetrahedron Lett. 1990, 3l, 4915 and references cited therein.

2. (a) Little, R. D.; Dawson, J. R. Tetrahedron Lett. 1980, 21, 2609. (b) Little, R. D.; Verhé, R.; Monte, W. T,; Nugent, S.; Dawson, J. R. J. Org. Chem. 1982, 47, 362. (c) Cooke, M. P., Jr. Tetrahedron Lett. 1979. 2199.

3. Fang, C.-L.; Suemune, H.; Sakai, K. J. Org. Chem. 1992, 57, 4300.

4. (a) Danishefsky, S. Acc. Chem. Res. 1979, 12, 66. (b) Abraham, N. A. Tetrahedron Lett. 1973, 451: see also; (c) Heming, A.; Sinai-Zingde, G.; Natchus, M.; Hudlicky, T. Tetrahedron Lett. 1987, 28, 167. (d) Morizawa, Y.; Oshima, K.; Nozaki, H. Israel J. Chem. 1984, 24, 149; and Tetrahedron Lett. 1982, 23, 2871. (e) Hashimoto, S.-I.; Shinoda, T.; Ikegami, S. Ibid, 1986, 27, 2885. (f) Larsen, S.D. J. Am. Chem. Soc. 1988, 110, 5932 .

5. (a) Ibuka, T.; Nakai, K.; Habashita, H.; Hotta, Y.; Fujii, N.; Mimura, N.; Miwa, Y.; Taga, T.; Yamamoto, Y. Angew. Chem. 1994, 106, 693. (b) Wipf, P.; Fritch, P. C. J. Org. Chem. 1994, 59, 4875.

6. Preparation of the aziridines, see: (a) Legters, J.; Thijs, L.; Zwanenburg, B. Tetrahedron Lett. 1989, 30 , 4881. Legters, J.; Thijs, L.; Zwanenburg, B. Recl. Trav. Chim. Pays-Bas 1992, 111, 1. (b) Legters, J. Ph.D. Thesis; 1991. Univ. of Nijmegen. 
7. Fugami, K.; Miura, K.; Morizawa, Y.; Oshima, K.; Utimoto, K.; Nozaki, H. Tetrahedron 1989, 45, 3089.

8. (a) Lehnert, W. Tetrahedron Lett. 1970, 4723. (b) Lehnert, W. Tetrahedron 1972, 28, 663. (c) Lehnert, W. Ibid, 1973, 29, 635. (d) Lehnert, W. Synthesis 1974, 667.

9. Yamanoto, Y.; Chounan, Y.; Nishii, S.; Ibuka, T.; Kitahara, H. J. Am. Chem. Soc. 1992, 114, 7652.

10. Yamamoto, Y. Angew. Chem., Int. Ed. Engl. 1986, 25, 947.

11. (a) Baldwin, J. E.; Adlington, R. M.; O'Neil, I. A.; Schofield, C.; Spivey, A. C.; Sweeney, J. B. J. Chem. Soc., Chem. Commun. 1989, 1852. (b) Tanner, D.; He, H. M.; Somfai, P. Tetrahedron 1992, 48, 6069. (c) Eis, M. J.; Ganem, B. Tetrahedron Lett. 1985, 26, 1153.

12. Marfat, A.; McGuirk, P. R.; Helquist, P. J. Org. Chem. 1979, 44, 3888.

13. Lipshutz, B. H.; Ellsworth, E. L.; Dimock, S. H.; Reuter, D. C. Tetrahedron Lett. 1989, 30, 2065.

14. Tanaka, K.; Minami, K.; Funaki,I.; Suzuki, H. Tetrahedron Lett. 1990, 31, 2727.

15. Fortunato, J. M.; Ganem, B. J. Org. Chem. 1976, 4l, 2194.

16. Influence of methyl substituent on ring-closure reactions, see: Benedetti, F.; Berto, F.; Fabrissin, S.; Gianferrara, T.; Risaliti, A. J. Org. Chem. 1991, 56, 3530.

17. The source of hydride is yet unknown. See also: Whitesides, G.M.; Stedronsky, E. R.; Casey, C. P.; San Filippo, J. J. Org. Chem., 1984, 49, 3928.

18. Upon introduction of the tosyl group to 3-alkyl-aziridine esters using tosyl chloride, chloride opened the $\mathrm{N}$-tosyl aziridine esters to a considerable extent after prolonged stirring ( 2 days). On the other hand, introduction of the mesitylsulfonyl group required stirring for 2 days. This process did not cause aziridine ring opening by chloride. These findings suggest that the mesitylenesulfonyl group activates the aziridine less than the tosyl group does. This might explain the absence of aziridine ring-opened products, such as 11 , in the reaction of $\mathbf{3 d}$.

19. Braun, H.; Huber, G. Tetrahedron Lett. 1976, 2121.

20. Hoffmann, R. Chem. Rev. 1989, 89, 1841.

21. (a) Cieplak, A. S. J. Am. Chem. Soc. 1981, 103, 4540. Cieplak, A. S.; Tait, B. D.; Johnson, C. R. Ibid, 1989, 111, 8447. (b) Lodge, E. P.; Heathcock, C. H. Ibid, 1987, 109, 3353.

22. (a) Dieter, R. K.; Tokles, M. J. Am. Chem. Soc. 1987, 109, 2040. (b) Corey, E. J.; Naef, R.; Hannon, F. J. Ibid, 1986, 108, 7114. (c) Tanaka, K.; Suzuki, H. J. Chem. Soc., Chem. Commun. 1991, 101.

23. Von Arx, E.; Faupel, M.; Brugger, M. J. J. Chromatogr. 1976, 120, 224.

24. Wakamiya, T.; Shimbo, K.; Shiba, T.; Nakajima, K.; Neya, M.; Okawa, K. Bull. Chem. Soc. Jpn. 1982, 55,3878 .

(Received in UK 28 May 1996; revised 26 July 1996; accepted 1 August 1996) 